Review

\title{
Sustainable Supply Chain Management and Multi-Criteria Decision-Making Methods: A Systematic Review
}

\author{
Ananna Paul ${ }^{1, *}$, Nagesh Shukla ${ }^{1}$, Sanjoy Kumar Paul ${ }^{2, *(D)}$ and Andrea Trianni ${ }^{1}$ (D) \\ 1 School of Information, Systems and Modelling, University of Technology Sydney, \\ Sydney, NSW 2007, Australia; Nagesh.Shukla@uts.edu.au (N.S.); Andrea.Trianni@uts.edu.au (A.T.) \\ 2 UTS Business School, University of Technology Sydney, Sydney, NSW 2007, Australia \\ * Correspondence: ananna.du@gmail.com (A.P.); sanjoy.paul@uts.edu.au (S.K.P.)
}

check for updates

Citation: Paul, A.; Shukla, N.; Paul, S.K.; Trianni, A. Sustainable Supply Chain Management and Multi-Criteria Decision-Making Methods: A Systematic Review. Sustainability 2021, 13, 7104. https:// doi.org/10.3390/su13137104

Academic Editor: Alessio Ishizaka

Received: 20 May 2021

Accepted: 21 June 2021

Published: 24 June 2021

Publisher's Note: MDPI stays neutral with regard to jurisdictional claims in published maps and institutional affiliations.

Copyright: (c) 2021 by the authors. Licensee MDPI, Basel, Switzerland. This article is an open access article distributed under the terms and conditions of the Creative Commons Attribution (CC BY) license (https:// creativecommons.org/licenses/by/ $4.0 /)$.

\begin{abstract}
Multi-criteria decision-making (MCDM) methods are smart tools to deal with numerous criteria in decision-making. These methods have been widely applied in the area of sustainable supply chain management (SSCM) because of their computational capabilities. This paper conducts a systematic literature review on MCDM methods applied in different areas of SSCM. From the literature search, a total of 106 published journal articles have been selected and analyzed. Both individual and integrated MCDM methods applied in SSCM are reviewed and summarized. In addition, contributions, methodological focuses, and findings of the reviewed articles are discussed. It is observed that MCDM methods are widely used for analyzing barriers, challenges, drivers, enablers, criteria, performances, and practices of SSCM. In recent years, studies have focused on integrating more than one MCDM method to highlight methodological contributions in SSCM; however, in the literature, limited research papers integrate multiple MCDM methods in the area of SSCM. Most of the published articles integrate only two MCDM methods, and integration with other methods, such as optimization and simulation techniques, is missing in the literature. This review paper contributes to the literature by analyzing existing research, identifying research gaps, and proposing new future research opportunities in the area of sustainable supply chain management applying MCDM methods.
\end{abstract}

Keywords: literature review; multi-criteria decision-making; MCDM methods; sustainable supply chain management; SSCM

\section{Introduction}

In this competitive era, every business is part of a supply chain which involves efficient and effective movement of products or services from suppliers through to customers via manufacturers, distributors, and retailers. A typical supply chain involves multiple businesses, resources, people, technologies, and information for buying, manufacturing, distributing, storing, and selling products [1]. Several activities within a supply chain present direct social, environmental, and economic impacts [2]. These impacts are referred to as the triple bottom line (TBL) in sustainable supply chain literature. Social impact includes modern slavery, gender discrimination, unfair wages, child labor, and so on $[3,4]$. Environmental impact includes emission of carbon dioxide, polluting water and the environment, global warming, and so on $[5,6]$. Economic impact includes the return of investment, impact on profit, and productivity [2]. Considering their significant impact on society, the environment, and the economy, every supply chain is now taking steps to ensure sustainability.

Sustainable supply chain management (SSCM) integrates the economic, social, and environmental goals of the supply chain to improve long-term performance [7], evaluating and monitoring business performance against social, environmental, and economic dimensions [2]. Any good social and environmental performance with economic performance ensures better sustainability; however, ensuring all three performances are good creates the 
best sustainable supply chain [8]. Some recent studies have considered the triple bottom line (TBL) aspect of supply chain sustainability [9-15].

Examples of social sustainability include ensuring fair policies, ethical practices, equal opportunities, diversity, and so on [16-18]. Several papers in the literature focused on different social sustainability dimensions in supply chains, such as wages, child labor, equal opportunities, discrimination, ethics, corruption, health safety, diversity, equity, human rights, labor practice, training, and slavery [16,17,19-21]. A summary of social sustainability in SSCM literature is presented in Table 1. Empirical research, together with the application of different MCDM methods, were widely used to identify and analyze the social dimension of SSCM (see Table 1). From the contributions presented in Table 1, one can note that most of the research studies analyzing social sustainability focused on barriers, enablers, criteria in service, and manufacturing supply chains.

When a supply chain is environmentally sustainable, it is known as a green supply chain [22]. Examples of an environmentally sustainable supply chain include the treatment of waste, recycling, environmental education and training, green purchasing, green manufacturing, and green design $[23,24]$. In recent studies in this area, MCDM methods were widely applied (see Table 2). Looking at Table 2, most of the research studies focused on evaluating or analyzing factors, indicators, criteria, practices, performances, and suppliers in green supply chains. Different characteristics, including recycling, remanufacturing, greenhouse gas emissions, waste management, environmental education and training, green design, green/cleaner production, green purchasing, green logistics/distribution, and energy consumption are considered [22-29]. We have summarized the different characteristics of environmental sustainability and their source studies in Table 2. 
Table 1. Different characteristics of social sustainability studied under SSCM literature.

\begin{tabular}{|c|c|c|c|c|c|c|c|c|c|c|c|c|c|c|c|}
\hline \multirow[b]{2}{*}{ Reference } & \multicolumn{13}{|c|}{ Characteristic Name } & \multirow[t]{2}{*}{ Contribution } & \multirow[t]{2}{*}{ Methodology } \\
\hline & Wages & $\begin{array}{l}\text { Child } \\
\text { Labor }\end{array}$ & $\begin{array}{l}\text { Equal Op- } \\
\text { portunity }\end{array}$ & Discrimination & Ethics & Corruption & $\begin{array}{l}\text { Health- } \\
\text { Safety }\end{array}$ & Diversity & Equity & $\begin{array}{c}\text { Human } \\
\text { Right }\end{array}$ & $\begin{array}{c}\text { Labor } \\
\text { Practice }\end{array}$ & Training & Slavery & & \\
\hline [19] & $\sqrt{ }$ & $\sqrt{ }$ & $\sqrt{ }$ & $\sqrt{ }$ & $\sqrt{ }$ & & $\sqrt{ }$ & $\sqrt{ }$ & $\sqrt{ }$ & $\sqrt{ }$ & $\sqrt{ }$ & $\sqrt{ }$ & & $\begin{array}{l}\text { Identification and } \\
\text { analysis of different } \\
\text { dimensions of social } \\
\text { sustainability in supply } \\
\text { chains in India }\end{array}$ & $\begin{array}{c}\text { Semi-structured } \\
\text { interview }\end{array}$ \\
\hline [16] & $\sqrt{ }$ & $\sqrt{ }$ & & & & & $\sqrt{ }$ & $\sqrt{ }$ & $\sqrt{ }$ & $\sqrt{ }$ & $\sqrt{ }$ & & & $\begin{array}{l}\text { Analyzing forces for } \\
\text { adopting social } \\
\text { sustainability in } \\
\text { emerging Indian and } \\
\text { Portuguese economies }\end{array}$ & Empirical study \\
\hline [30] & $\sqrt{ }$ & $\sqrt{ }$ & & & & $\sqrt{ }$ & & & & $\sqrt{ }$ & $\sqrt{ }$ & & $\sqrt{ }$ & $\begin{array}{l}\text { Analyzing modern } \\
\text { slavery in supply chains } \\
\text { perspective of United } \\
\text { Kingdom from the } \\
\text { clothing and textile sector }\end{array}$ & $\begin{array}{l}\text { Secondary data } \\
\text { analysis }\end{array}$ \\
\hline [31] & $\sqrt{ }$ & $\sqrt{ }$ & $\sqrt{ }$ & $\sqrt{ }$ & & & $\sqrt{ }$ & $\sqrt{ }$ & $\sqrt{ }$ & $\sqrt{ }$ & $\sqrt{ }$ & $\sqrt{ }$ & & $\begin{array}{l}\text { Analyzing relationships } \\
\text { between enablers to the } \\
\text { social sustainability }\end{array}$ & ISM-MICMAC \\
\hline [18] & & & & & & & $\sqrt{ }$ & & & $\sqrt{ }$ & $\sqrt{ }$ & $\sqrt{ }$ & & $\begin{array}{l}\text { Selecting supplier bases } \\
\text { social sustainable criteria }\end{array}$ & $\begin{array}{l}\text { Grey } \\
\text { BWM-grey } \\
\text { TODIM }\end{array}$ \\
\hline [21] & $\sqrt{ }$ & $\sqrt{ }$ & & $\sqrt{ }$ & $\sqrt{ }$ & $\sqrt{ }$ & $\sqrt{ }$ & $\sqrt{ }$ & $\sqrt{ }$ & $\sqrt{ }$ & & $\sqrt{ }$ & $\sqrt{ }$ & $\begin{array}{l}\text { Investigating integrated } \\
\text { aspects of social } \\
\text { sustainability }\end{array}$ & Empirical study \\
\hline [4] & $\sqrt{ }$ & $\sqrt{ }$ & & $\sqrt{ }$ & & $\sqrt{ }$ & $\sqrt{ }$ & & & & & $\sqrt{ }$ & & $\begin{array}{l}\text { Analyzing enablers in } \\
\text { social sustainability in } \\
\text { footwear supply chains }\end{array}$ & BWM \\
\hline [17] & $\sqrt{ }$ & $\sqrt{ }$ & $\sqrt{ }$ & & $\sqrt{ }$ & $\sqrt{ }$ & $\sqrt{ }$ & & & $\sqrt{ }$ & & $\sqrt{ }$ & $\sqrt{ }$ & $\begin{array}{l}\text { Addressing social } \\
\text { sustainability in supplier } \\
\text { selection processes }\end{array}$ & $\begin{array}{l}\text { Exploratory } \\
\text { case study }\end{array}$ \\
\hline [32] & & & & & $\sqrt{ }$ & & $\sqrt{ }$ & & $\sqrt{ }$ & $\sqrt{ }$ & & $\sqrt{ }$ & & $\begin{array}{l}\text { Analyzing dimensions of } \\
\text { social sustainability in } \\
\text { healthcare supply chains }\end{array}$ & $\begin{array}{l}\text { Stochastic } \\
\text { exponential } \\
\text { distribution } \\
\text { model }\end{array}$ \\
\hline [33] & & & & & & & $\sqrt{ }$ & & & $\sqrt{ }$ & $\sqrt{ }$ & $\sqrt{ }$ & & $\begin{array}{l}\text { Investigating social } \\
\text { sustainability criteria } \\
\text { Identifying motivators, }\end{array}$ & BWM \\
\hline [34] & & & $\sqrt{ }$ & & $\sqrt{ }$ & & $\sqrt{ }$ & & $\sqrt{ }$ & & & $\sqrt{ }$ & & $\begin{array}{l}\text { barriers, and enablers of } \\
\text { social sustainability }\end{array}$ & Empirical study \\
\hline [20] & $\sqrt{ }$ & $\sqrt{ }$ & $\sqrt{ }$ & $\sqrt{ }$ & $\sqrt{ }$ & & $\sqrt{ }$ & & & $\sqrt{ }$ & $\sqrt{ }$ & $\sqrt{ }$ & $\sqrt{ }$ & $\begin{array}{l}\text { Developing a taxonomy } \\
\text { of supply chain social } \\
\text { sustainability practices }\end{array}$ & Empirical study \\
\hline
\end{tabular}


Table 2. Different characteristics of environmental sustainability studied under SSCM literature.

\begin{tabular}{|c|c|c|c|c|c|c|c|c|c|c|c|c|c|c|}
\hline \multirow[b]{2}{*}{ Reference } & \multicolumn{12}{|c|}{ Characteristic Name } & \multirow{2}{*}{ Contribution } & \multirow{2}{*}{ Methodology } \\
\hline & Recycling & Remanufacturing & $\begin{array}{c}\text { Circular } \\
\text { Economy }\end{array}$ & $\begin{array}{l}\text { Greenhouse Gas } \\
\text { Emission }\end{array}$ & $\begin{array}{c}\text { Waste Treat- } \\
\text { ment/Management }\end{array}$ & $\begin{array}{c}\text { Use of Natural } \\
\text { Resources }\end{array}$ & $\begin{array}{l}\text { Environmental } \\
\text { Education and } \\
\text { Training }\end{array}$ & Green Design & $\begin{array}{c}\text { Green/Cleaner } \\
\text { Production }\end{array}$ & $\begin{array}{c}\text { Green } \\
\text { Purchasing }\end{array}$ & $\begin{array}{c}\text { Green Logis- } \\
\text { tics/Distribution }\end{array}$ & $\begin{array}{c}\text { Energy } \\
\text { Consumption } \\
\end{array}$ & & \\
\hline [25] & $\checkmark$ & & & $\checkmark$ & & & $\checkmark$ & $\checkmark$ & & $\checkmark$ & & & $\begin{array}{l}\text { Identifiying } \\
\text { critical } \\
\text { dimensions and } \\
\text { factorsin green } \\
\text { supply chains } \\
\end{array}$ & $\begin{array}{l}\text { DEMATEL and } \\
\text { cast study }\end{array}$ \\
\hline [26] & $\checkmark$ & $\checkmark$ & & $\checkmark$ & $\checkmark$ & & & $\checkmark$ & $\checkmark$ & $\checkmark$ & $\checkmark$ & & $\begin{array}{c}\text { Evaluating } \\
\text { indicators in } \\
\text { green supply } \\
\text { chains } \\
\end{array}$ & Fuzzy VIKOR \\
\hline [22] & $\checkmark$ & & & $\checkmark$ & $\checkmark$ & $\checkmark$ & & $\checkmark$ & $\checkmark$ & $\checkmark$ & & $\checkmark$ & $\begin{array}{c}\text { Evaluating } \\
\text { suppliers in } \\
\text { green supply } \\
\text { chain }\end{array}$ & Literature review \\
\hline [29] & $\checkmark$ & $\checkmark$ & & $\checkmark$ & $\checkmark$ & & & $\checkmark$ & & $\checkmark$ & & $\checkmark$ & $\begin{array}{l}\text { Analyzing critical } \\
\text { green supply } \\
\text { chain practices }\end{array}$ & FIPA approach \\
\hline [23] & $\checkmark$ & & & $\checkmark$ & $\checkmark$ & $\checkmark$ & $\checkmark$ & $\checkmark$ & $\checkmark$ & $\checkmark$ & $\checkmark$ & $\checkmark$ & $\begin{array}{c}\text { Analyzing } \\
\text { criteria for green } \\
\text { supply chains } \\
\end{array}$ & Fuzzy DEMATEL \\
\hline [28] & $\checkmark$ & & $\checkmark$ & $\checkmark$ & $\checkmark$ & & & $\checkmark$ & $\checkmark$ & $\checkmark$ & $\checkmark$ & $\checkmark$ & $\begin{array}{c}\text { Developing an } \\
\text { assessment } \\
\text { framework for } \\
\text { green supply } \\
\text { chain } \\
\text { management }\end{array}$ & Conceptual study \\
\hline [24] & $\checkmark$ & $\checkmark$ & & $\checkmark$ & $\checkmark$ & & $\checkmark$ & $\checkmark$ & & $\checkmark$ & $\checkmark$ & $\checkmark$ & $\begin{array}{l}\text { Evaluating green } \\
\text { suppliers }\end{array}$ & TOPSIS \\
\hline
\end{tabular}


Examples of economic sustainability include cost reduction, on-time delivery, reliability, and quality [11]. Sustainable supply chains simultaneously assess supply chain performance in terms of social, environmental, and economic aspects.

In the last few years, a good number of studies have been conducted on different dimensions of SSCM, including a number of review papers, such as a:

- review of green supply chain management [35-37];

- review of different theories in sustainable supply chains [38];

- review of the evolution of and future challenges in sustainable supply chain management [8,39-41];

- review of trends and future directions in social aspects of sustainable supply chains [42];

- review of SSCM in global supply chain context [43];

- review of drivers in SSCM [44]; and

- review of MCDM methods in green supply chains which focuses only on the environmental dimension of supply chain management [22,45].

In order to become more sustainable, supply chains should implement sustainable practices, with a certain impact on various TBL areas; however, decision makers need to consider multiple criteria to evaluate suppliers, practices, success factors, drivers, and challenges in SSCM in smart ways. For this purpose, MCDM methods have been widely applied in the area of SSCM [46]. In spite of having a reasonable number of contributing articles which applied different MCDM methods in SSCM, earlier literature is lacking a review on different MCDM methods applied to SSCM areas considering the social, environmental, and economic dimensions. In this paper, we aim to fill this gap by conducting a literature review on different MCDM methods applied in SSCM, contributing to the literature by analyzing existing studies systemically and proposing a future research framework in the area of MCDM methods in SSCM.

The paper is organized as follows. In Section 2, the scope of the literature review is described. The review of both individual and integrated MCDM methods is conducted in Section 3. Section 4 explains the bibliometric analysis for published articles. Section 5 summarizes the review and research gaps. Finally, conclusions and future research directions are presented in Section 6.

\section{Scope of the Literature Review}

The Scopus database was used to collect the relevant articles with the following phrases in the article's title, abstract, and keywords: "sustainable supply chain" and "multicriteria decision making" or "multi-criteria decision analysis" or "MCDM". From the preliminary search of the literature, most of the studies in the area of SSCM modelling were found to be published since 2010, which is shown in Figure 1. Based on this observation, in this paper, the literature on MCDM methods applied in the area of SSCM is reviewed from 2010 to 2020.

After the preliminary search in Scopus, the search database was refined using the following criteria:

- Document type: article

- $\quad$ Source type: journals

- Year: 2010-2020

- Language: English

Other databases, such as the Web of Science and Google Scholar, were used to enhance the search. After a first screening of the articles (by title and abstract), the final subset of 106 relevant manuscripts for review was created. The inclusion criteria were articles focused on any dimension of supply chain sustainability and the search phrases appeared in the body text. The exclusion criterion was one or more keywords presented in the text or reference list without discussing supply chain sustainability using MCDM methods. After finalizing the list of articles, a deep review was conducted of the applications of different 
MCDM methods in SSCM, and a bibliometric analysis was carried out within the set of finalized articles.

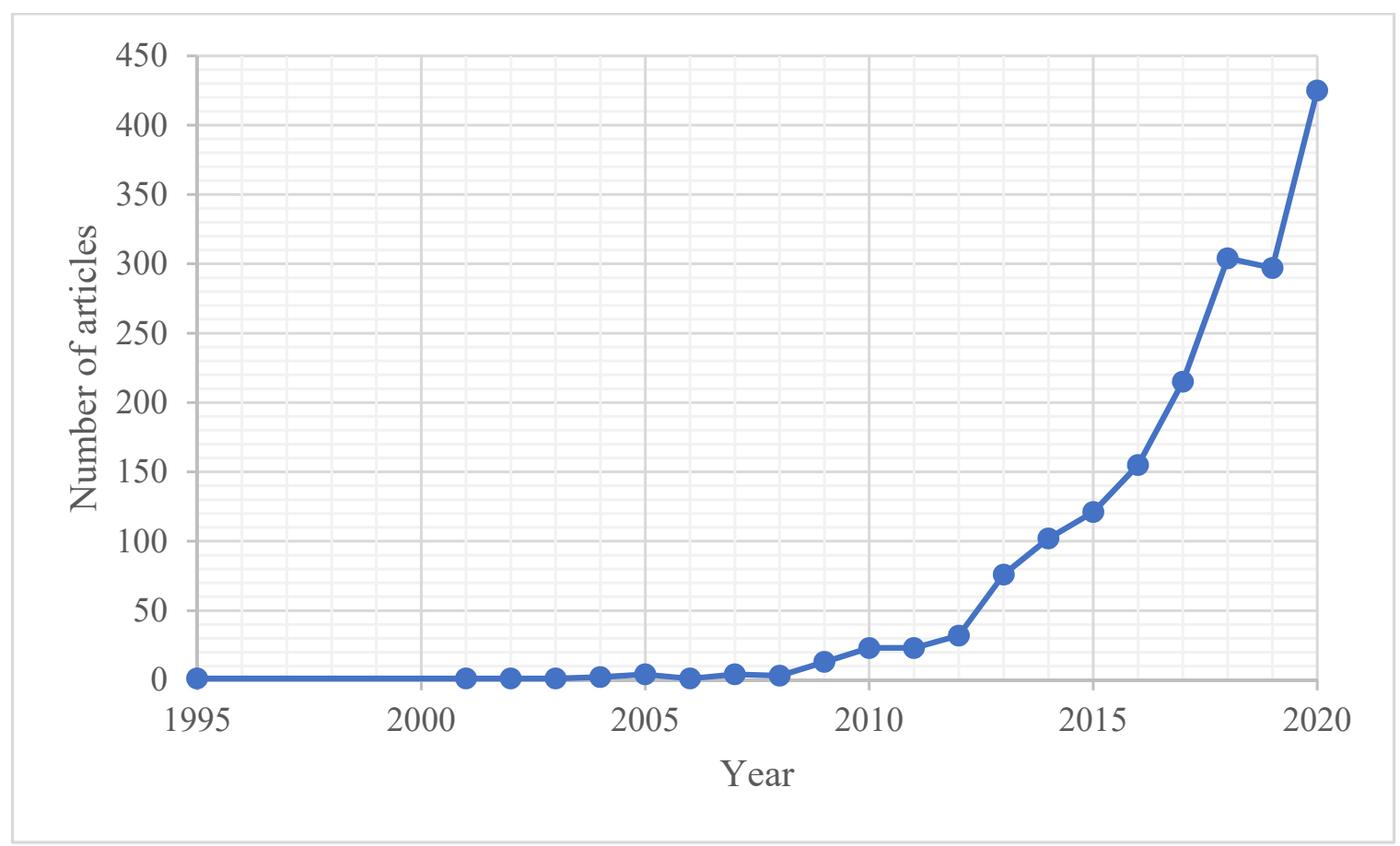

Figure 1. Number of articles published on SSCM modelling (Source: Scopus).

\section{Review of Applications of MCDM Methods in SSCM}

This section reviews the articles on MCDM methods applied in SSCM areas. The following sub-sections review the applications of both individual and integrated MCDM methods in detail.

\subsection{Applications of Individual MCDM Methods}

From the literature search, 59 articles applied individual MCDM methods in SSCM. The names of the methods and their abbreviated terms are as follows:

i. Decision-making trial and evaluation laboratory (DEMATEL) and Fuzzy/Grey DEMATEL

ii. Analytical hierarchy process (AHP) and Fuzzy AHP

iii. The technique for order of preference by similarity to ideal solution (TOPSIS) and Fuzzy TOPSIS

iv. Best-worst method (BWM)

v. VIseKriterijumska Optimizacija I Kompromisno Resenje (VIKOR) and Fuzzy VIKOR

vi. Rough set

vii. Elimination et choix traduisant la realité (ELECTRE) and Fuzzy ELECTRE

viii. Analytical network process (ANP)

ix. Rough strength-relation analysis method (RSRAM)

$\mathrm{x}$. Rough simple additive weighting (RSAW)

xi. Interpretive structural modelling (ISM)

xii. Preference ranking organization method for enriched evaluation (PROMETHEE)

\subsubsection{DEMATEL and Fuzzy/Grey DEMATEL}

DEMATEL and Fuzzy/Grey DEMATEL are the most applied methods in SSCM. Between 2010 and 2020, a total of 15 articles have been published on this method. Among these, six articles applied DEMATEL, four applied grey DEMATEL, and five articles applied fuzzy DEMATEL. 
In particular, applications of DEMATEL include the identification and analysis of success factors for sustainability initiatives (grey [47]), sustainable food supply chain management [48], green supply chain practices (fuzzy [49]), SSCM for Industry 4.0 [50], and implementing green supply chain management [51]. In addition, DEMATEL was used in a number of studies to analyze and evaluate barriers or challenges for sustainable development [52], remanufacturing (grey [53]), and green supply chain [54]. A few studies also analyzed drivers for sustainable consumption and production adoption applying grey DEMATEL [55] and drivers to ICT for sustainability initiatives in supply chains using a fuzzy one [56]. DEMATEL was used in other applications including the analysis of criteria and alternatives in sustainable supply chains (grey [57]), evaluation of influential indicators for adopting sustainable supply chains [58], analysis of causal relationships between practices and performance in green supply chains (fuzzy [59]), assessing performance in green supply chains considering economic, logistics, operational, organizational, and marketing aspects (fuzzy [23]), and selection of suppliers based on multiple criteria (fuzzy [60]).

\subsubsection{AHP and Fuzzy AHP}

AHP is one of the most widely applied MCDM methods in SSCM. Eleven articles applied AHP or Fuzzy AHP. Among these, six articles applied AHP, and the remaining five articles applied the fuzzy AHP method.

Six studies applied AHP to evaluate barriers to adopting sustainable consumption and production initiatives [61], to analyze criteria for improving effectiveness in green supply chain management implementation [62], to analyze challenges for industry 4.0 initiatives toward SSCM [63], to evaluate pressures to implement GSCM [64], to evaluate manufacturing practices for sustainability [65], and to analyze drivers for sustainable manufacturing processes [66]. Fuzzy AHP was also used to identify and analyze risks in green supply chains [67], analyze success factors for sustainable food supply chain management [68], evaluate indicators of SSCM [69], assess the supply chain performance based on sustainability criteria [70], and evaluate European countries for renewable energy sectors [71].

\subsubsection{TOPSIS and Fuzzy TOPSIS}

Earlier studies applied TOPSIS (two articles) or fuzzy TOPSIS (six articles) in the context of SSCM. The applications encompass the suppliers' evaluation and selection in sustainable and green supply chains based on multiple criteria. These criteria include applications of TOPSIS in selecting sustainable suppliers [72,73] and applications of fuzzy TOPSIS in evaluating green supplier performance [74,75], evaluating sustainable and green suppliers $[24,76,77]$, and assessing areas for improvement in implementing green supply chain initiatives [78].

Researchers applied TOPSIS and Fuzzy TOPSIS to select suppliers and performance in sustainable or green supply chains based on identified multi-criteria.

\subsubsection{BWM}

The eight articles which have applied BWM in SSCM include an assessment of sustainability in green supply chains in an emerging economy [79], assessment of social sustainability in supply chains [33], evaluation of external forces for sustainable supply chains in the context of the oil and gas industries [80], analysis of enablers for social sustainability in an emerging economy [4], evaluation and prioritization of criteria for sustainable innovation [13], analysis of product-package alternatives in food supply chains [81], ranking sustainable suppliers [82], and analyzing barriers for sustainable supply chain innovation [83].

\subsubsection{VIKOR and Fuzzy VIKOR}

Five articles applied VIKOR or fuzzy VIKOR in SSCM. These articles include evaluating green supply chain management practices using fuzzy VIKOR [26], selecting devel- 
opment programs for green suppliers using fuzzy VIKOR theory [84], evaluating green environmental factors in reverse logistics using fuzzy VIKOR [85,86], and assessing green supply chain initiatives using a probabilistic linguistic VIKOR method [87].

\subsubsection{Rough Set}

The Rough set method has been applied in SSCM to select suppliers with sustainability [88], analyzing relationships between organizational attributes, supplier development programs, and performance in green supply chains [89], evaluating a selection, performance measurement, and program development tool in green supply chains [90], and measuring SSCM performances [91].

\subsubsection{ELECTRE and Fuzzy ELECTRE}

ELECTRE and fuzzy ELECTRE have been applied in SSCM to classify suppliers in the manufacturing industry using the ELETCRE TRI-nC method [92] and to evaluate supplier performance in green supply chains using the fuzzy ELECTRE method [93].

\subsubsection{ANP}

Two studies applied the ANP method in SSCM. The applications include selecting suppliers for managing sustainability [94] and selecting suppliers integrating the triplebottom-line aspect [95].

\subsubsection{Rough Strength-Relation Analysis Method, RSAW, ISM, and PROMETHEE}

One article applied the Rough strength-relation analysis method for analyzing risk factors in SSCM [96], the RSAW for sustainable supplier selection [97], the ISM for ranking of barriers in SSCM [98], and the PROMETHEE for analyzing alternatives of biomass [99].

\subsubsection{Summary of Applications of Individual Methods}

Researchers applied DEMATEL and Fuzzy/Grey DEMATEL, AHP, and BWM mostly for analyzing success factors, barriers and challenges, drivers, and enablers for different aspects of SSCM. Success factors are the important factors decision makers should consider to ensure success in different dimensions of SSCM. Barriers and challenges are the causes preventing the success of any dimension of SSCM. Drivers and enablers are the aspects driving toward the achievement of sustainable performance within any dimension of supply chain sustainability. The different MCDM methods applied to analyze and prioritize success factors, barriers and challenges, and drivers and enablers in SSCM are summarized in Tables 3-5, respectively.

Table 3. Application of MCDM methods to analyze success factors.

\begin{tabular}{ccc}
\hline Analyzed Success Factors in SSCM & Reference & Method \\
\hline $\begin{array}{c}\text { Green design, recovering and recycling, green } \\
\text { purchasing, environmental performance, supplier } \\
\text { collaboration, and regulation }\end{array}$ & {$[49]$} & Fuzzy DEMATEL \\
\hline $\begin{array}{c}\text { Government regulations and standards, top } \\
\text { management commitment, environmental certifications, } \\
\text { adoption of new technology and processes, reverse } \\
\text { logistics, and training of suppliers and employees }\end{array}$ & {$[51]$} & DEMATEL \\
\hline $\begin{array}{c}\text { Logistics integration, social development, and } \\
\text { environmental development }\end{array}$ & [50] & DEMATEL
\end{tabular}


Table 3. Cont.

\begin{tabular}{ccc}
\hline Analyzed Success Factors in SSCM & Reference & Method \\
\hline $\begin{array}{c}\text { Technology development and process innovation, } \\
\text { training, reverse logistics and waste minimization, } \\
\text { ecological considerations in organizations' policies and } \\
\text { missions, green design and purchasing, societal } \\
\text { considerations, ethical and safe practices, and } \\
\text { community welfare and development }\end{array}$ & [47] & Grey DEMATEL \\
\hline $\begin{array}{c}\text { Climatic change, implementing green practice, } \\
\text { governance and cooperation, technological innovation, } \\
\text { and government regulation }\end{array}$ & {$[48]$} & DEMATEL \\
\hline $\begin{array}{c}\text { Proper use of irrigation, demographic and } \\
\text { environmental conditions, risk analysis, government } \\
\text { policies, and food packaging }\end{array}$ & {$[68]$} & Fuzzy AHP \\
\hline
\end{tabular}

Table 4. Applications of MCDM methods to analyze barriers and challenges.

\begin{tabular}{|c|c|c|}
\hline Analyzed Barriers and Challenges in SSCM & Reference & Method \\
\hline $\begin{array}{l}\text { Lack of sufficient governmental policies, poor } \\
\text { infrastructure, low level of integration, skill shortage, } \\
\text { and poor quality of raw materials }\end{array}$ & [52] & DEMATEL \\
\hline $\begin{array}{l}\text { Lack of channels to collect used products, imperfect } \\
\text { legal system, consumption attitude, customer } \\
\text { willingness to return the products, uncertainty in } \\
\text { demand of remanufactured product, uncertainty in } \\
\text { quality, and quantity and timing of returned products }\end{array}$ & [53] & Grey DEMATEL \\
\hline $\begin{array}{l}\text { Lack of environmental regulation, lack of potential } \\
\text { liability, high cost of disposal of hazardous materials, } \\
\text { poor environmental performance, lack of information, } \\
\text { lack of governmental support, high cost for renewable } \\
\text { energy, lack of new technology, insufficient societal } \\
\text { pressure, poor legislation, lack of adoption of green } \\
\text { practices, health and safety issues, employment stability, } \\
\text { less profit in remanufacturing, lack of adequate training, } \\
\text { and lack of management support }\end{array}$ & [54]. & DEMATEL \\
\hline $\begin{array}{l}\text { Lack of support from management, lack of innovative } \\
\text { methods, lack of technology developments, } \\
\text { communication gap, lack of rewards and } \\
\text { encouragement programs, lack of governmental } \\
\text { regulations, lack of promotion of ethical and safe } \\
\text { practices, reluctance of consumers toward sustainable } \\
\text { development practices, lack of promotion of sustainable } \\
\text { products, and lack of knowledge among stakeholders }\end{array}$ & [61] & AHP \\
\hline $\begin{array}{l}\text { Low understanding of industry } 4.0 \text { implications, poor } \\
\text { research and development of industry } 4.0 \text { adoption, } \\
\text { legal issues, low management support and dedication, } \\
\text { lack of global standards and data-sharing protocols, } \\
\text { security issues, lack of governmental support and } \\
\text { policies, and financial constraints }\end{array}$ & [63] & AHP \\
\hline $\begin{array}{l}\text { Technological, regulatory, social, cultural, } \\
\text { organizational, market, and networking barriers }\end{array}$ & [83] & BWM \\
\hline
\end{tabular}


Table 5. Applications of MCDM methods for analyzing drivers and enablers.

\begin{tabular}{|c|c|c|}
\hline Analyzed Drivers and Enablers in SSCM & Reference & Method \\
\hline $\begin{array}{l}\text { Top management role and support, government support } \\
\text { systems and subsidies, information systems network } \\
\text { design, socio-environmental impacts of the products, } \\
\text { culture related factors, approach to ICT to adopt } \\
\text { sustainability, understanding the nature of sustainability, } \\
\text { security and support services, and human expertise }\end{array}$ & [56] & Fuzzy DEMATEL \\
\hline $\begin{array}{l}\text { Management support, dedication and involvement, } \\
\text { educating suppliers and vendors, understanding the } \\
\text { customer requirements about sustainability, } \\
\text { governmental policies and regulations, information flow } \\
\text { and sharing among supply chain members, competency } \\
\text { and skill of workforce, integration of social, } \\
\text { environmental, and economic advantages, and } \\
\text { understanding the importance of sustainability }\end{array}$ & [55] & Grey DEMATEL \\
\hline $\begin{array}{c}\text { Market capabilities, compliance with regulations, green } \\
\text { purchasing, green innovation, environmental } \\
\text { conservation, education and training, and employee } \\
\text { welfare }\end{array}$ & {$[66]$} & AHP \\
\hline $\begin{array}{l}\text { Commitment to continual improvement and pollution } \\
\text { prevention, commitment to comply with legislation, } \\
\text { framework for setting and reviewing environmental } \\
\text { goals, legal and other requirements, environmental } \\
\text { objectives and targets, environmental education and } \\
\text { training, green teamwork, best practices, identification } \\
\text { of culture, monitoring culture change, quantity of waste } \\
\text { released at each stage, and communication between top } \\
\text { management and employees }\end{array}$ & {$[62]$} & AHP \\
\hline $\begin{array}{c}\text { Waste management, reuse and recycle, renewable } \\
\text { energy usage, resource utilization, land, air and water } \\
\text { pollution, government regulations, and use of } \\
\text { hazardous materials }\end{array}$ & [79] & BWM \\
\hline $\begin{array}{l}\text { Wages and benefits, customer requirements, workplace } \\
\text { health and } \\
\text { safety practices, food, housing, and sanitation, child } \\
\text { labor or forced labor, commitment of top management, } \\
\text { education and training of employees, } \\
\text { non-discrimination, anti-corruption, and working hours }\end{array}$ & [4] & BWM \\
\hline $\begin{array}{l}\text { Sustainable product cost reduction, financial availability } \\
\text { for innovation, enhanced sustainability value to } \\
\text { customers, investment in R\&D for sustainable products, } \\
\text { designing sustainable products, green logistics } \\
\text { capabilities development, green manufacturing, } \\
\text { environment management commitment, conducting } \\
\text { regular environmental audits, enhancing the social } \\
\text { image of the organization, corporate social } \\
\text { responsibility initiatives, cultural, social values and } \\
\text { norms, occupational health, and safety and rights of the } \\
\text { employees }\end{array}$ & [13] & BWM \\
\hline
\end{tabular}

Researchers applied TOPSIS, Fuzzy TOPSIS, VIKOR, Rough Set, and ANP to analyze and evaluate suppliers and practices in sustainable or green supply chains based on sustainable criteria. These studies are summarized in Table 6. 
Table 6. Summary of applications in analyzing and evaluating suppliers and practices.

\begin{tabular}{|c|c|c|c|}
\hline Sustainable Criteria Considered & Application Area & Reference & Method \\
\hline $\begin{array}{l}\text { Pollution controls, pollution prevention, } \\
\text { environmental management system, } \\
\text { resource consumption, employment } \\
\text { practices, health and safety, local } \\
\text { communities influence, stakeholders } \\
\text { influence, cost, quality, and innovation }\end{array}$ & $\begin{array}{l}\text { Supplier selection in } \\
\text { sustainable supply chain }\end{array}$ & [73] & TOPSIS \\
\hline $\begin{array}{l}\text { Cost reduction activities, products' } \\
\text { quality improvement, increase in supply } \\
\text { flexibility, green design of products, } \\
\text { green purchasing, green production, } \\
\text { internal management support for green } \\
\text { development, green logistics, provision } \\
\text { for health and safety, protection of } \\
\text { employee's rights, human rights, and } \\
\text { fair-trading and against corruption }\end{array}$ & $\begin{array}{l}\text { Supplier selection in } \\
\text { sustainable supply chain }\end{array}$ & [72] & TOPSIS \\
\hline $\begin{array}{l}\text { Quality of products, service } \\
\text { performance, cost, environmental } \\
\text { efficiency, green image, pollution } \\
\text { reduction, green competencies, health } \\
\text { and safety, and employment practices }\end{array}$ & $\begin{array}{c}\text { Supplier selection in } \\
\text { sustainable supply chain }\end{array}$ & [77] & $\begin{array}{l}\text { Fuzzy } \\
\text { TOPSIS }\end{array}$ \\
\hline
\end{tabular}

Cost, financial capability, flexibility, innovation, service capability, environmental management system, green image, greenhouse gas emission, reuse/recycling, pollution control, energy and resource consumption, economic welfare and growth, social responsibility, job safety and labor health, the interest and rights of employees, and job opportunities

\begin{tabular}{cccc}
\hline $\begin{array}{c}\text { Green design, green purchasing, green } \\
\text { production, green warehousing, green } \\
\text { transportation, and green recycling }\end{array}$ & Green practice evaluation & {$[26]$} & $\begin{array}{c}\text { Fuzzy } \\
\text { VIKOR }\end{array}$ \\
\hline $\begin{array}{c}\text { Cost, resource usage, energy usage, } \\
\text { water consumption, emission and waste } \\
\text { generation, green manufacturing, } \\
\text { product design, transportation, } \\
\text { warehouse and procurement, and } \\
\text { reverse logistics }\end{array}$ & $\begin{array}{c}\text { Evaluation of green } \\
\text { supplier development } \\
\text { program }\end{array}$ & [84] & VIKOR \\
$\begin{array}{c}\text { Cost, quality, time, flexibility, } \\
\text { innovation, culture, technology, } \\
\text { relationships, pollution control and } \\
\text { prevention, resource consumption, } \\
\text { health and safety, employment practices, } \\
\text { and local community influence }\end{array}$ & $\begin{array}{c}\text { Supplier selection in } \\
\text { sustainable supply chain }\end{array}$ & [88] & Rough Set \\
\hline $\begin{array}{c}\text { Quality, price, on-time delivery, lead } \\
\text { time, flexibility, community initiatives, } \\
\text { ethical behavior, health and safety, } \\
\text { diversity, waste reduction, recycling, } \\
\text { and reverse logistics }\end{array}$ & $\begin{array}{c}\text { Supplier selection in } \\
\text { sustainable supply chain }\end{array}$ & [95] & ANP \\
\hline
\end{tabular}

\subsection{Applications of Integrated MCDM Methods}

A total of 47 articles applied integrated MCDM methods in SSCM. Among these, AHP or Fuzzy AHP were most widely integrated with other methods such as DEMATEL, ELECTRE, ISM, TOPSIS, VIKOR, and SOWIA, followed by TOPSIS or Fuzzy TOPSIS with 
FPP, Rough set, CRITIC, and VIKOR. Researchers have applied more integrated MCDM methods in recent years, making a significant methodological contribution; this section summarizes such studies.

AHP and Fuzzy AHP are mostly integrated with TOPSIS or fuzzy TOPSIS and VIKOR and fuzzy VIKOR. AHP-TOPSIS is widely applied in selecting sustainable or green suppliers, evaluating third-party logistics (3PL) service providers, and prioritizing solutions and responses in different aspects of SSCM [100-105]. AHP-VIKOR (with their fuzziness) integrated method was mostly applied for selecting a sustainable supplier and management practices in green supply chain management [106-108]. Other integrations of AHP or fuzzy AHP with DEMATEL or fuzzy DEMATEL, ELECTRE or fuzzy ELECTRE, ISM, and SOWIA were applied in analyzing success factors [109], barriers [110], enablers [111], and strategy decisions [112] in SSCM or green supply chain management.

ANP is mostly integrated with quality function deployment (QFD) to analyze supplier selection and environmental sustainability, and for designing sustainable supply chains [113-116]. Other integrations of ANP with VIKOR [117] and grey rational analysis (GRA) [118] were applied in green/sustainable supplier evaluation.

BWM or fuzzy BWM is mostly integrated with VIKOR or fuzzy VIKOR for evaluating transportation service providers and outsourcing partners based on sustainable criteria $[119,120]$. Other applications of integrated BWM or fuzzy BWM include evaluating dimensions of human resources in green supply chains using BWM-DEMATEL [121], selecting sustainable suppliers in manufacturing supply chains by integrating BWM and an alternative queuing method (AQM) [122] and selecting sustainable suppliers using integrated BWM and combined compromise solution [123].

TOPSIS or Fuzzy TOPSIS is mostly integrated with VIKOR or fuzzy VIKOR, fuzzy preference programming (FPP), Rough set, and criteria importance through intercriteria correlation (CRITIC). TOPSIS-VIKOR (and their fuzziness) integrated methods [124,125] were applied in selecting third-party reverse logistics service providers and classifying rural areas based on social sustainability criteria. TOPSIS-VIKOR-GRA (integrating three methods) was applied in analyzing locations for remanufacturing plants based on multiple criteria [126]. Other applications of integrated TOPSIS or fuzzy TOPSIS include evaluating supply chain practices by integrating TOPSIS and Rough set [127], analyzing risk factors in SSCM using TOPSIS-CRITIC [128], and selecting sustainable suppliers using TOPSISFPP [129].

Other integrated methods, such as ELECTRE with VIKOR, were applied in environmental performance evaluation [130]; DEMATEL with MABAC was applied in sustainable freight transport systems [131]; RSAW with MABAC applied in sustainable supplier selection [132]; factor relationship (FARE) with MABAC for selecting third-party logistics provider [133]; step-wise weight assessment ratio analysis (SWARA) and fuzzy complex proportional assessment of alternatives (COPRAS) were used for analyzing risks and solutions in sustainable manufacturing supply chains [134]; and fuzzy entropy and fuzzy multi-attribute utility were applied for sustainable performance measure in supply chain [135].

In summary, most of the integrated MCDM methods in SSCM were used for evaluating or analyzing suppliers, service providers, barriers, enablers, success factors, and evaluating performance. A summary of different integrated MCDM methods applied in SSCM is presented in Table 7. 
Table 7. Summary of integrated MCDM methods applied in SSCM.

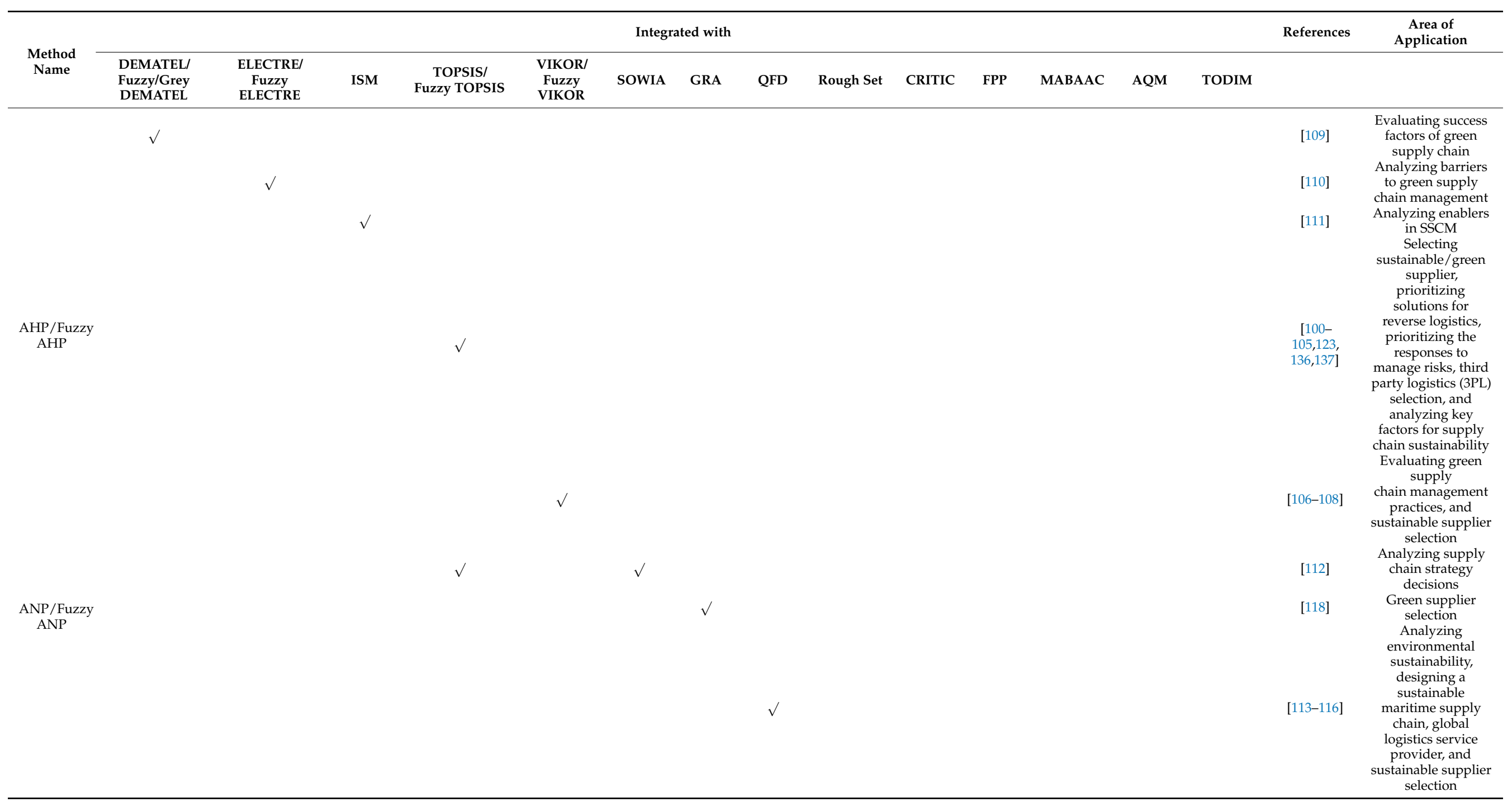


Table 7. Cont.

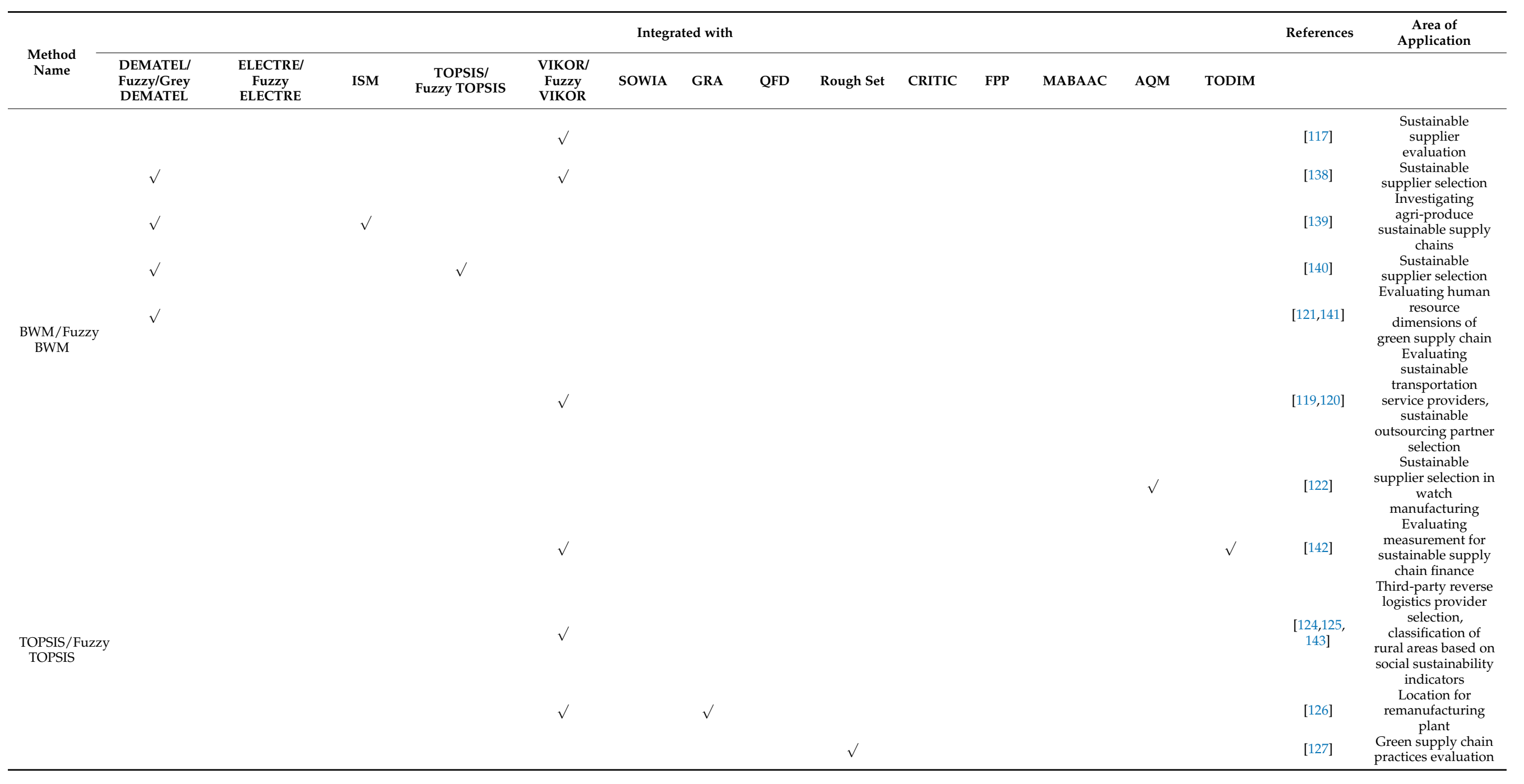


Table 7. Cont.

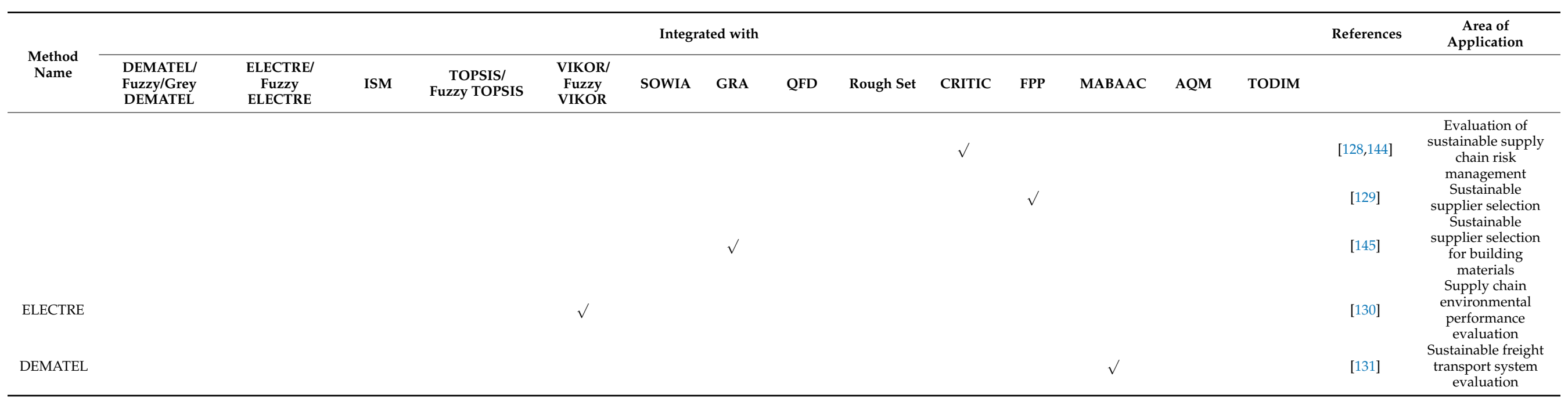




\section{Bibliometric Analysis on MCDM Methods Applied to SSCM}

This section presents a bibliometric analysis of MCDM methods applied to SSCM. From the finalized literature search (see Section 2), we can note a lack of reviews, with only five studies (about $4.5 \%$ ) reviewing particular topics such as: (i) green supplier evaluation and selection [22]; (ii) modelling approaches in SSCM [146]; (iii) MCDM approaches in green supply chains [45]; (iv) hybrid MCDM for general sustainability [147]; and (v) sustainable supplier selection [148]. In total, 106 contributing articles (about 95.5\%) applied MCDM methods to better understand SSCM issues; this means, Figure 2 presents the keyword network obtained from the keywords used in each of the contributing articles. It is evident that supply chain management, decision-making, sustainable development, sustainability, and green supply chains, environmental management, and sustainable supply chains are the top keywords. Figures 3 and 4 present the citation networks of selected contributing papers based on source journals and authors, respectively. The Journal of Cleaner Production and International Journal of Production Economics are two leading cited journals. Govindan, K., and Mangla, S.K. are two leading cited authors.

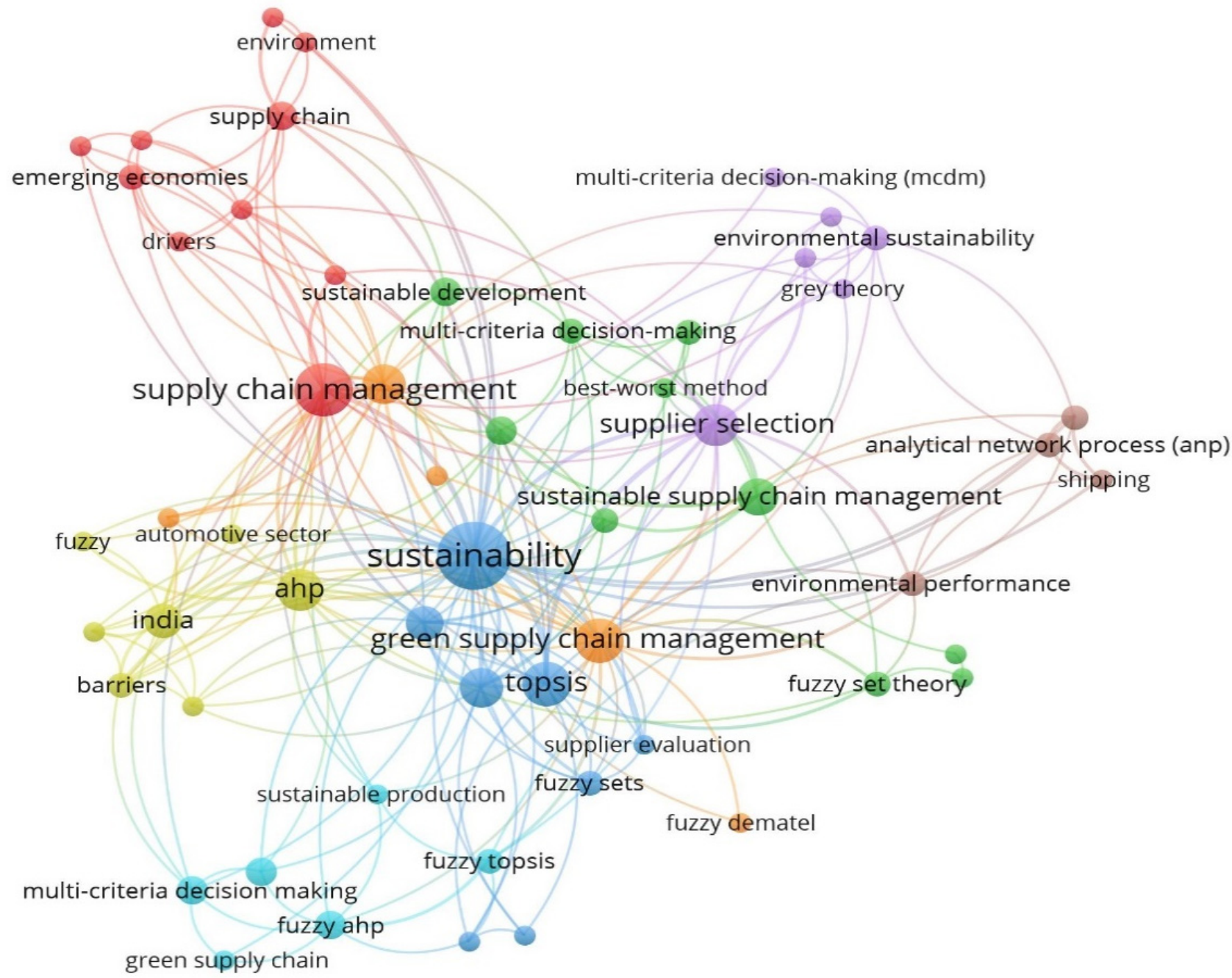

Figure 2. Co-occurrence of keywords used in the selected contributing papers (source: VOSviewer). 


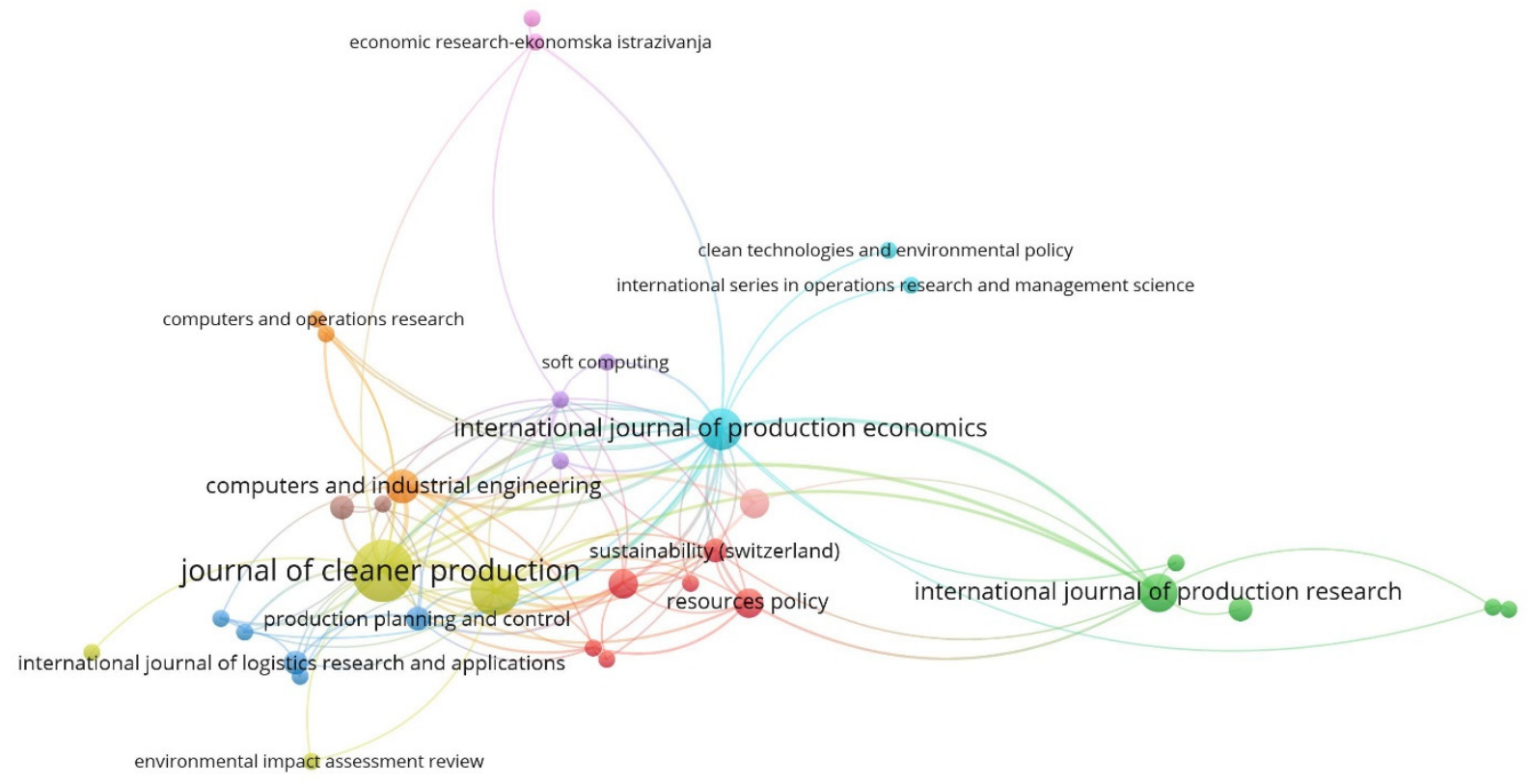

Figure 3. Co-occurrence of citation network from the source journals of the selected articles (source: VOSviewer).

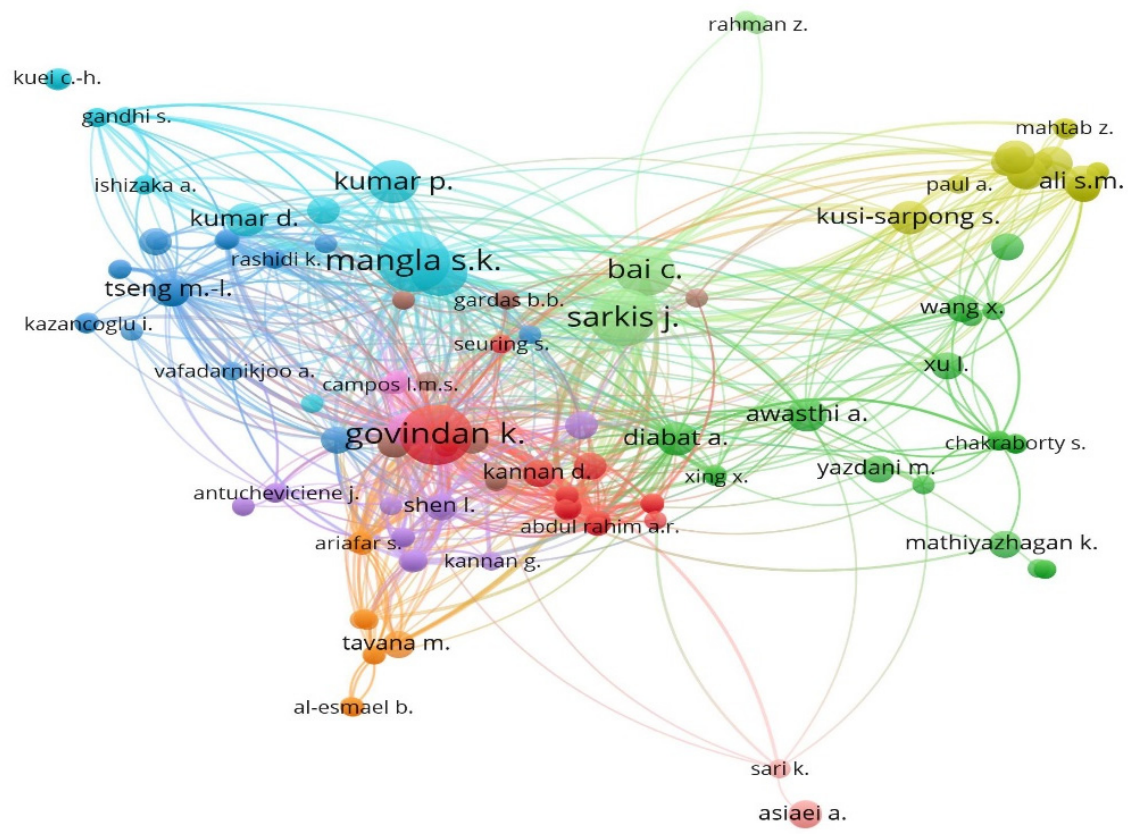

Figure 4. Co-occurrence of citation network from the authors of the selected articles (source: VOSviewer).

The number of contributing articles published from 2010 to 2020 is shown in Figure 5. From 2015, researchers started publishing an increasing number of articles applying MCDM methods in SSCM. The Journal of Cleaner Production (Publisher: Elsevier, Amsterdam, The Netherlands) has published the highest number of articles (18 articles), followed by Resource, Conservation and Recycling (Publisher: Elsevier), the International Journal of Production Economics (Publisher: Elsevier), Sustainability (Publisher: MDPI, Basel, Switzerland), and the International Journal of Production Research (Publisher: Taylor and Francis, Oxfordshire, UK). The number of articles published in each of these journals is presented in Figure 6. 


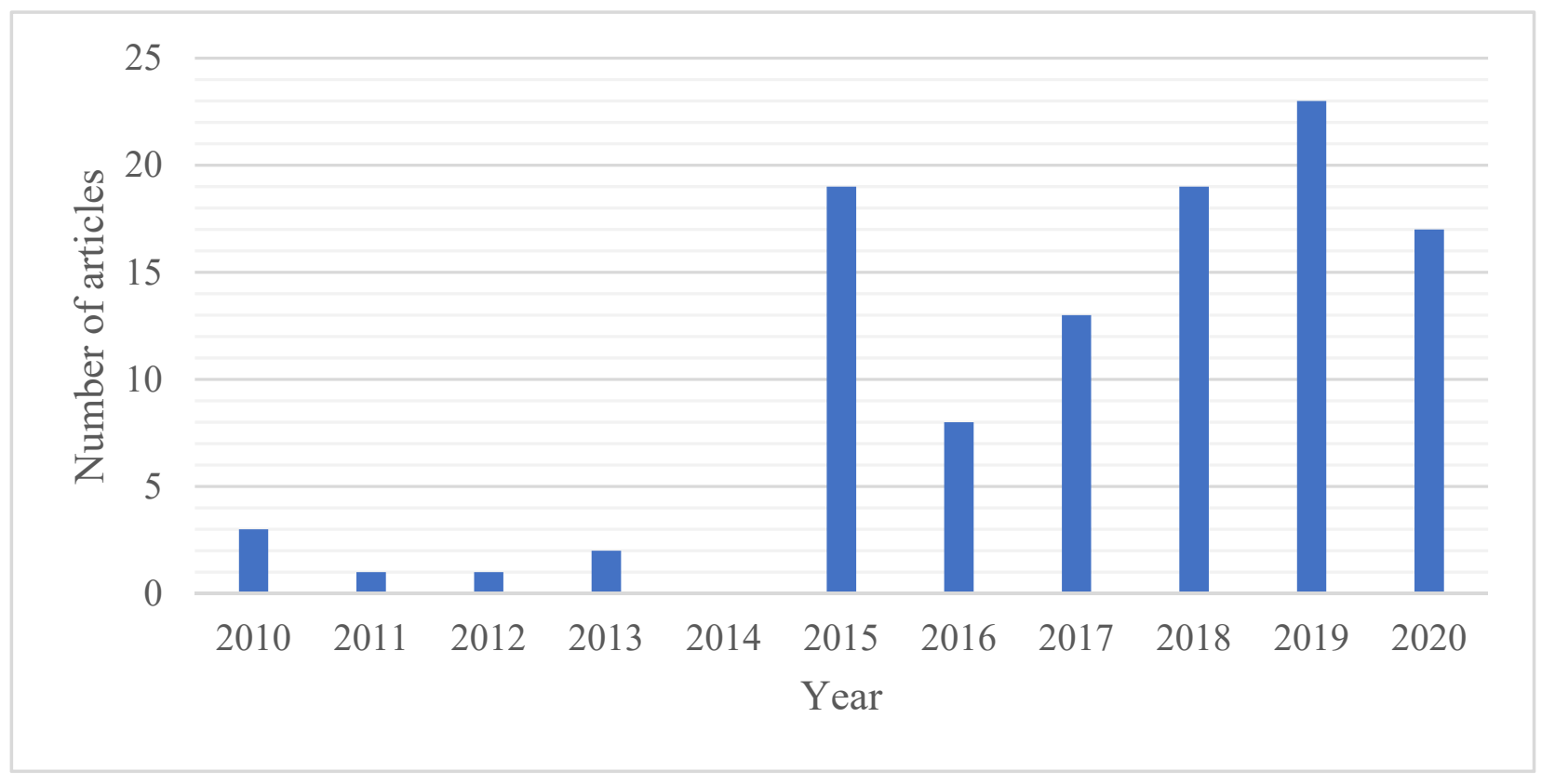

Figure 5. Number of articles published from 2010 to 2020.

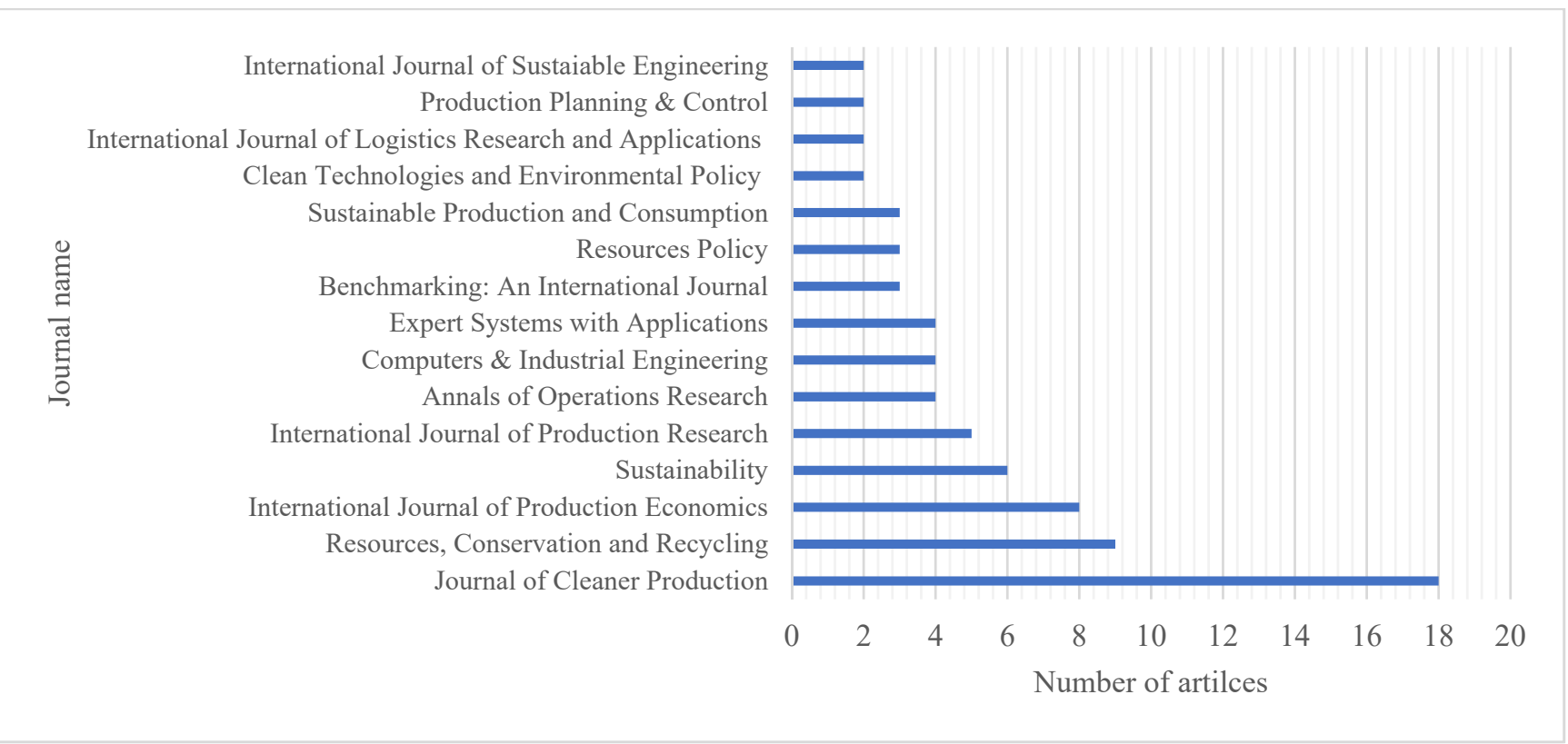

Figure 6. Number of articles published in different journals $(\mathrm{N} \geq 2)$.

Figure 7 presents the authors who published the most articles in the area of MCDM for SSCM. Both Govindan, K. and Mangla, S.K. are at the top of the list, with 10 published articles, followed by Sarkis, J., Bai, C., and Luthra, S. with 9, 7, and 6 articles, respectively.

The affiliation by authors' institutions is also presented in Figure 8. Syddansk Universitet (University of Southern Denmark) is at the top of the list with 12 articles, followed by the Indian Institute of Technology Roorkee (India) and Dalian University of Technology (China). The affiliated countries which published most articles are presented in Figure 9. India is at the top of the list with 27, followed by China, the United States, and Denmark with 19,15 , and 12 articles, respectively. 


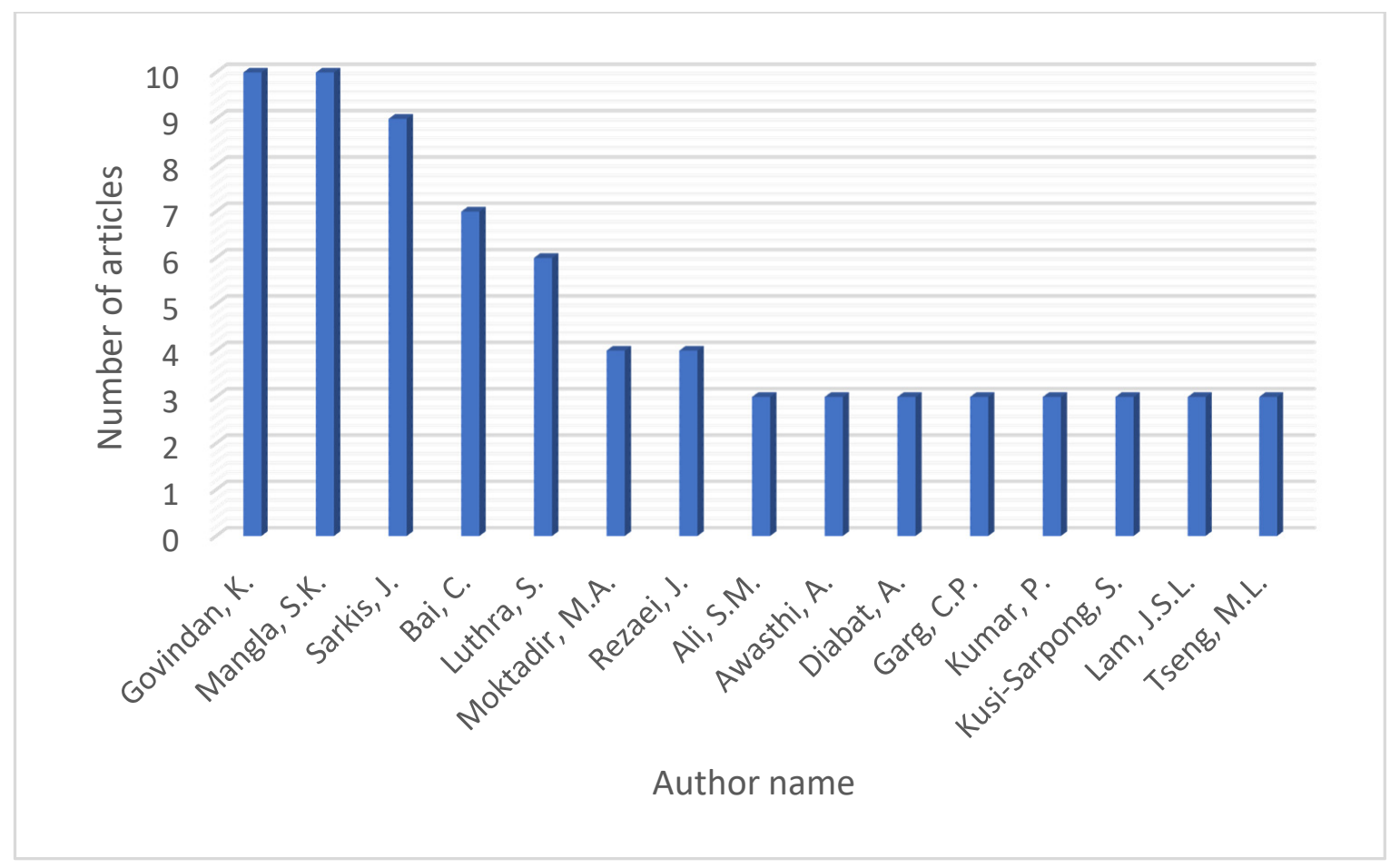

Figure 7. Articles published by different authors $(\mathrm{N} \geq 3)$.

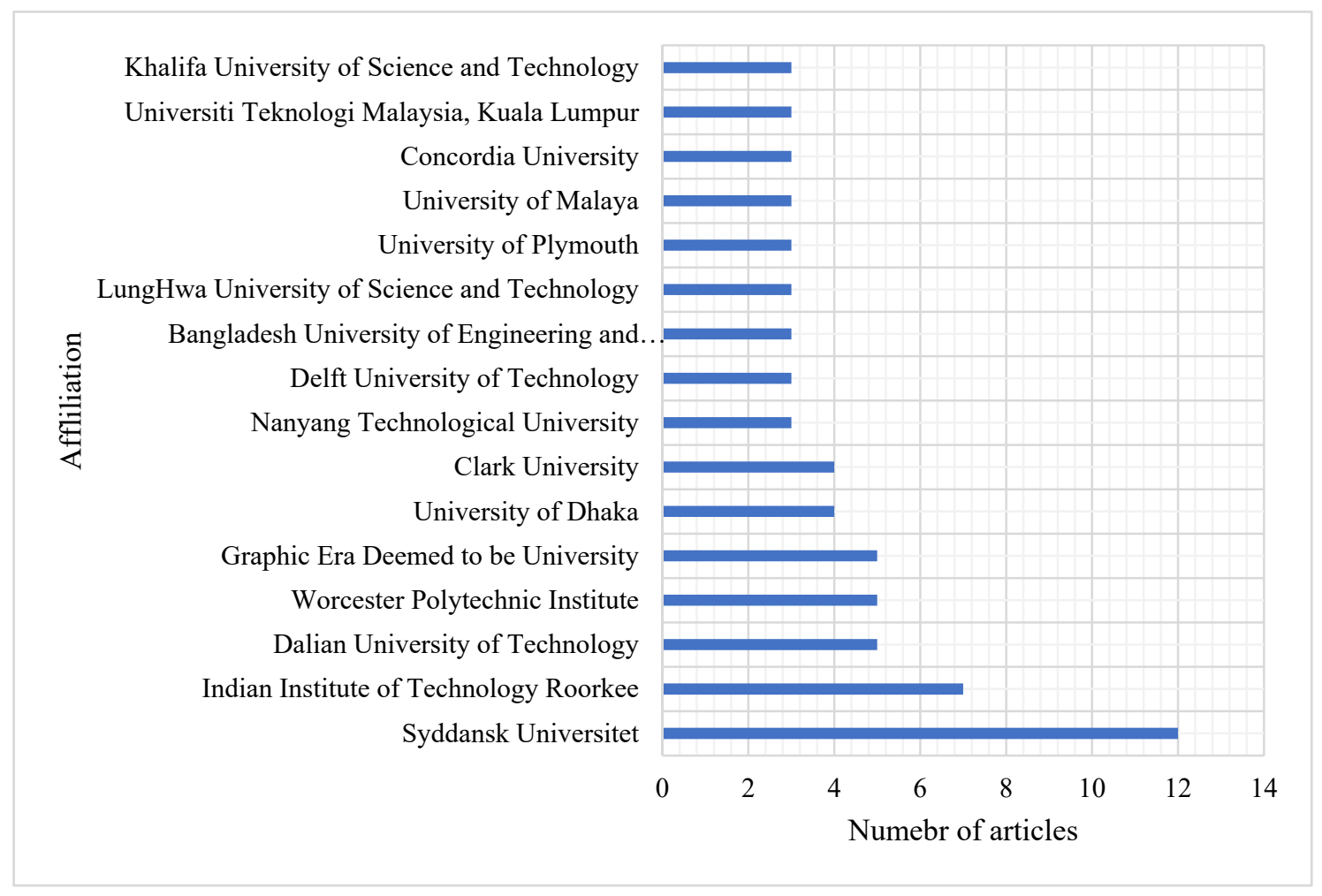

Figure 8. Most affiliated institutions $(\mathrm{N} \geq 3)$. 


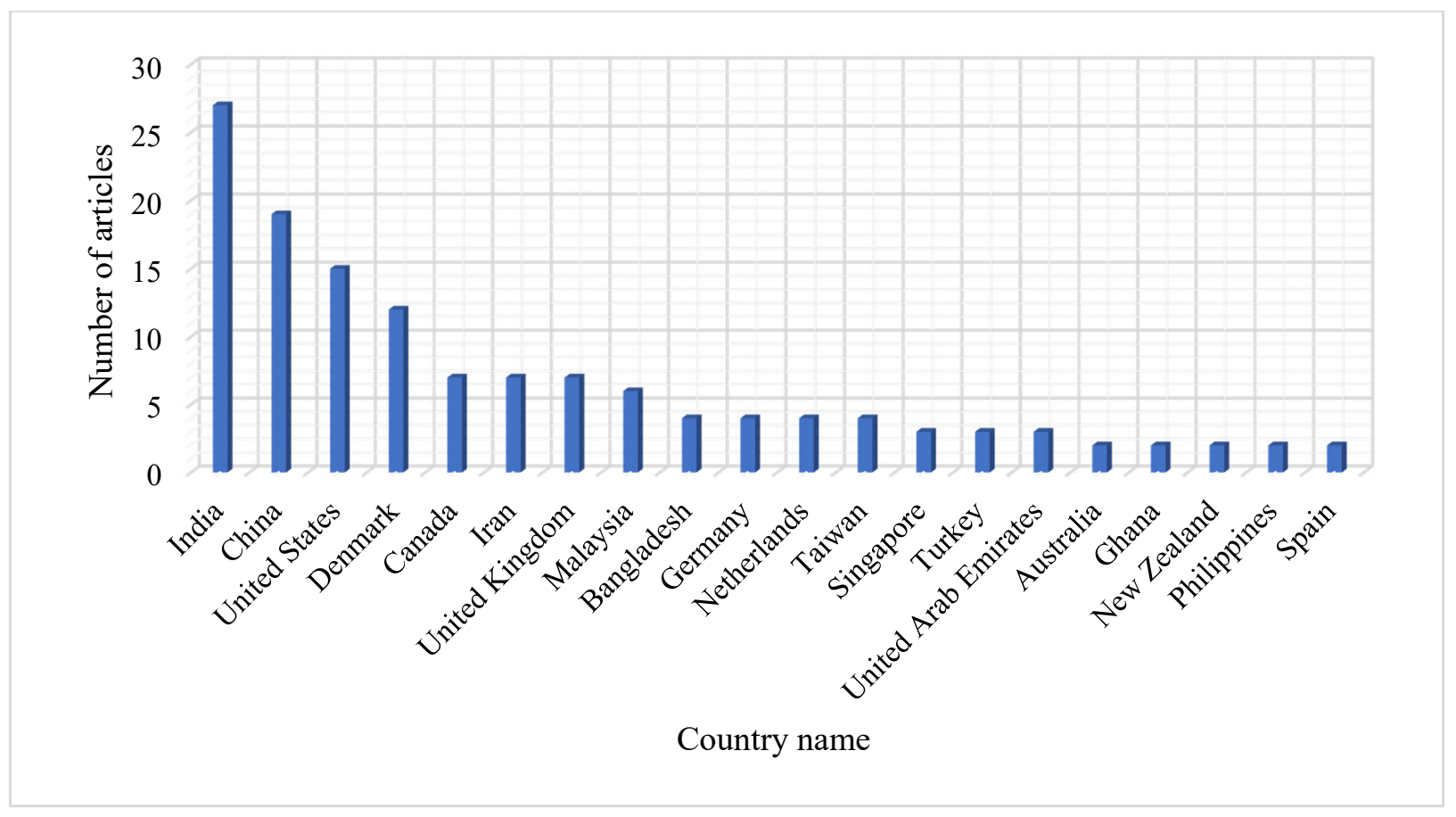

Figure 9. Source countries for publications $(\mathrm{N} \geq 3)$.

Fifty-nine articles (about 56\%) used individual MCDM methods for problem analysis, while the remaining 47 articles (about $44 \%$ ) used integrated (two or more methods) methods. Figure 10 shows that integrated or hybrid MCDM methods were mostly applied in SSCM. Within individual MCDM methods: DEMATEL, AHP, and TOPSIS are the top three methods applied in SSCM literature.

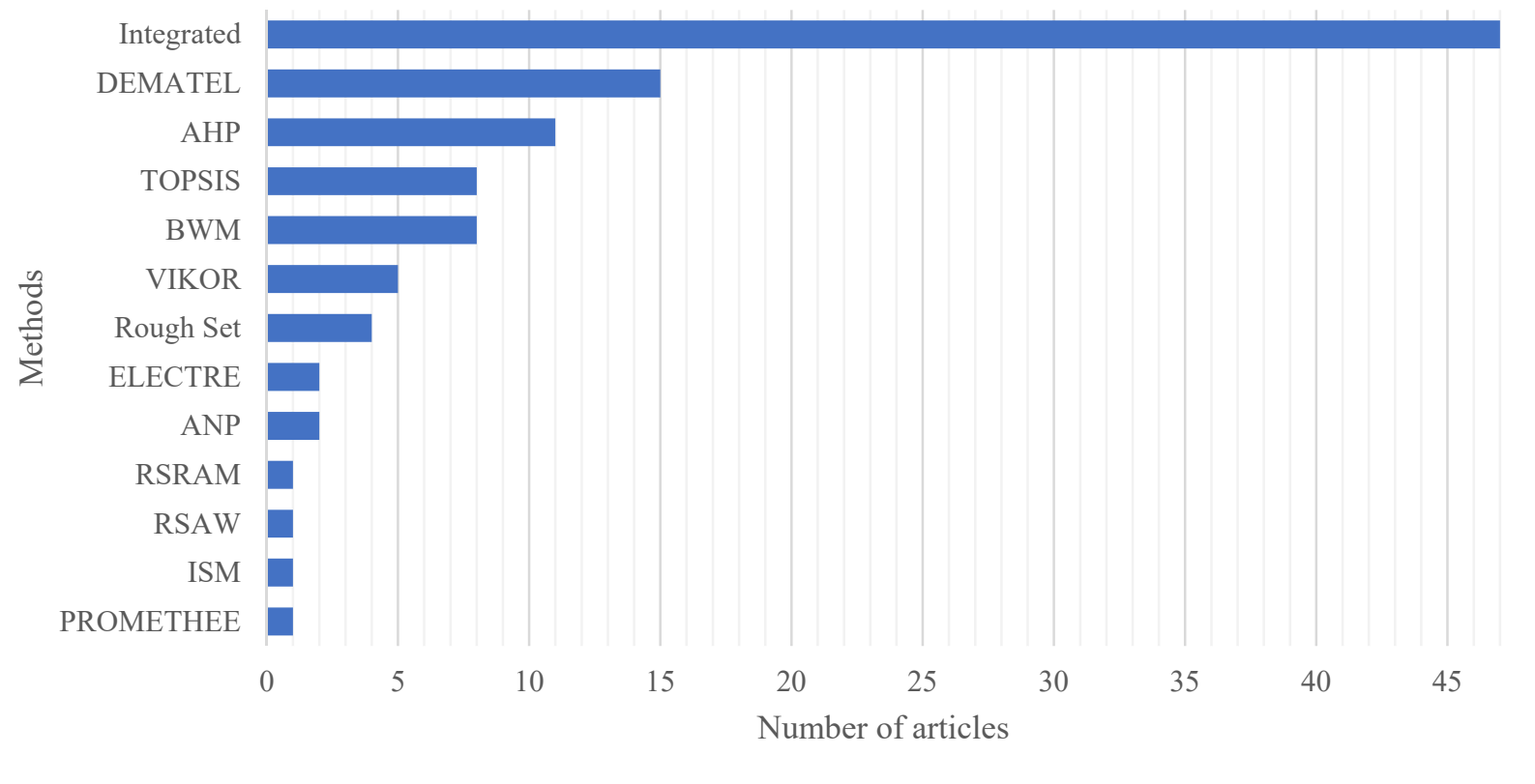

Figure 10. Distribution of contributing articles under different MCDM methods. 


\section{Summary of the Review and Research Gaps}

The following key points present a summary of the extensive literature review and its findings.

Firstly, Section 3 described the application of different MCDM methods in SSCM, showing most studies applied an individual or two integrated MCDM methods, with a lack of studies integrating three or more MCDM methods for analyzing different dimensions of sustainability in supply chain management. Only a few studies integrated three methods (see Table 7); for example, AHP integrated with SOWIA and TOPSIS [112], TOPSIS integrated with GRA and VIKOR [126], and ANP integrated with DEMATEL and TOPSIS [140].

Secondly, in SSCM, most of the studies contributed to advancing the methodology by integrating different MCDM methods. MCDM methods were integrated within AHP, ANP, BWM, TOPSIS, ELECTRE, DEMATEL, ISM, VIKOR, SOWIA, GRA, QFD, Rough set, CRTIC, FPP, MABAAC, and AQM along with their fuzzy sets (see Table 7). It was observed that both single and integrated MCDM methods were applied, but there is a lack of studies which integrate MCDM methods with other operations research methods to improve the accuracy in decision making. For example, the integration of MCDM methods with mathematical modelling and optimization could help to obtain optimal decisions in SSCM.

Thirdly, most of the research considered social sustainability, environmental sustainability, and/or triple bottom line in the scope of their studies. Tables 6 and 7 presented the areas of application of individual and integrated MCDM methods. The application areas of MCDM methods were limited to different aspects of sustainability. Most of the studies integrated MCDM methods in models for green supply chains (see Table 7). Most of the studies on individual MCDM methods applied them in evaluating factors, barriers, challenges, drivers, enablers, and suppliers in different SSCM areas (see Tables 3-6).

Fourthly, most SSCM researchers limit their studies to analyzing factors, barriers, challenges, drivers, enablers, and suppliers (see Section 3). There are fewer studies that integrate sustainable strategies and performance with barriers/challenges and drivers/enablers using integrated MCDM methods.

Fifthly, from Section 3, most of the studies explained their results using individual or integrated MCDM methods. There are limited studies which compared the results between different MCDM methods. For example, there is only one study comparing fuzzy DEA and fuzzy TOPIS in sustainable supplier selection [76].

Finally, earlier literature largely overlooked small and medium enterprises (SMEs) and the emerging economy as study contexts for MCDM applied in SSCM. A small number of articles considered SMEs as their context, analyzing drivers for integrated lean-green manufacturing [149], innovation ability for supplier selection [150], determinants for cloud computing adoption [151], and entrepreneurship policies [152].

\section{Conclusions and Future Research Directions}

This paper presented a literature review on MCDM methods applied in different dimensions of SSCM. Although there have been many papers published in the area of SSCM, there are very few review papers published. A systematic literature analysis and review to identify different domains of supply chain sustainability and applications of different MCDM methods was lacking. Contributing to the academic discussion on this topic, this is the first effort to analyze both individual and integrated MCDM methods applied in different areas of supply chain sustainability.

Findings revealed the following important aspects of previous studies.

i. Most of the research applied either individual or integrated methods of two MCDM techniques. All of the integrated MCDM methods applied were carried out in recent years, i.e., after 2015.

ii. Since 2015, environmental and social sustainability have been garnering the attention of researchers (see Tables 1 and 2). In recent years, several MCDM methods, such 
as ISM-TOPSIS [31], grey BWM-grey TODIM [18], and BWM [4,33] were applied in social sustainability while DEMATEL [25], fuzzy DEMATEL [23], fuzzy VIKOR [26], and TOPSIS [24] were applied in environmental sustainability areas.

iii. Most of the individual methods analyzed barriers, drivers, enablers, challenges, success factors, forces, and criteria in SSCM and green supply chains (see Tables 3-6).

iv. Integrated MCDM methods were applied in evaluating and analyzing sustainable suppliers and different alternatives in SSCM (see Table 7).

v. There are very few studies which integrated three or more MCDM methods and applied them in SSCM [112,126].

In conclusion, we would like to acknowledge some study limitations and propose some future research directions. At present, the study has been limited to three databases: Scopus (primary), Web of Science, and Google Scholar. Therefore, potential additional sources of information and knowledge such as conference proceedings or books not indexed in the three databases have not been included. Further, the research was limited to documents published in English exclusively, therefore potentially excluding local contributions redacted in other languages. Additionally, as there is limited research on the integration of three or more MCDM methods, it would be interesting to develop new integrated methodologies with three or more MCDM methods for decision-making in SSCM. Moreover, the fuzzy BWM method is a newly developed tool that can optimize a decision based on multiple criteria [153]. Currently, few studies apply BWM and fuzzy BWM in SSCM [4,13,79,119-122]. In the future, BWM and Fuzzy BWM could be applied widely in SSCM. In addition, the literature is lacking contributions able to integrate barriers and challenges with strategies and analyzes using an integrated MCDM method. In this regard, further research could explore the following research question: 'How can sustainable strategies be analyzed along with barriers and challenges to extend the current studies using MCDM methods?'

In the current literature, there is no study that correlated success factors, enablers, and drivers with sustainability performance analyzed using integrated MCDM methods. Hence, future research could address how barriers, challenges, drivers, enablers, and/or success factors can be linked with strategies and performance in one study, so as to develop a unique research framework using MCDM methods. In addition, it would be significantly new to the literature to integrate different aspects of SSCM with other supply chain areas such as risk management, lean supply chains, quality management, and supply chain network design. For example, the recent coronavirus (COVID-19) pandemic has impacted supply chains significantly [154]. It would be worth investigating the impacts of large-scale disruptions such as the COVID-19 pandemic in supply chain sustainability. Different MCDM methods can be applied to investigate different aspects of impacts on sustainable practices.

Our review pointed out that though service supply is an important area, research on applications of MCDM methods in sustainable service supply chains is very limited [130]. Different dimensions of sustainability in service supply chain management could be explored using MCDM methods.

In the future, another research direction could be integrating MCDM methods with operations research techniques, such as mathematical modelling and optimization, to make decisions more accurate. For example, integration of MCDM methods with mathematical modelling and optimization techniques could help to take optimal and accurate decision making in SSCM. Moreover, as there is only one study comparing the results of MCDM methods [76], it is necessary to develop benchmark problems and compare the results obtained from different MCDM methods used in SSCM. It would also be interesting to compare the sustainability results between supply chains from developed and emerging economies.

Finally, as SMEs and emerging economies play significant roles in local and global supply chains $[155,156]$, it is important to analyze the sustainability of supply chains of SMEs and emerging economies. Usually, SMEs and emerging economies have fewer 
resources to deal with supply chain sustainability challenges. Hence, it is essential to analyze their supply chain sustainability and develop policies for improving sustainability practices. However, in the literature of MCDM methods and SSCM, SMEs and emerging economies were widely ignored. It would be interesting to develop decision-making tools using MCDM methods for analyzing different aspects of supply chain sustainability in the context of SMEs and emerging economies.

Author Contributions: Conceptualization, A.P.; methodology, A.P.; formal analysis, A.P.; investigation, A.P.; data curation, A.P.; writing — original draft preparation, A.P.; writing—review and editing, N.S., S.K.P., and A.T.; visualization, A.P. and S.K.P.; supervision, N.S. and A.T.; project administration, N.S. and A.T. All authors have read and agreed to the published version of the manuscript.

Funding: This research received no external funding.

Institutional Review Board Statement: Not applicable.

Informed Consent Statement: Informed consent was obtained from all subjects involved in the study. Data Availability Statement: Not Applicable.

Acknowledgments: This research is supported by an Australian Government Research Training Program Scholarship.

Conflicts of Interest: The authors declare no conflict of interest.

\section{References}

1. Paul, S.K.; Sarker, R.; Essam, D. A quantitative model for disruption mitigation in a supply chain. Eur. J. Oper. Res. 2017, 257, 881-895. [CrossRef]

2. Mota, B.; Gomes, M.I.; Carvalho, A.; Barbosa-Povoa, A.P. Towards supply chain sustainability: Economic, environmental and social design and planning. J. Clean. Prod. 2015, 105, 14-27. [CrossRef]

3. Giannakis, M.; Papadopoulos, T. Supply chain sustainability: A risk management approach. Int. J. Prod. Econ. 2016, 171, 455-470. [CrossRef]

4. Munny, A.A.; Ali, S.M.; Kabir, G.; Moktadir, M.A.; Rahman, T.; Mahtab, Z. Enablers of social sustainability in the supply chain: An example of footwear industry from an emerging economy. Sustain. Prod. Consum. 2019, 20, 230-242. [CrossRef]

5. Green, K.W.; Zelbst, P.J.; Meacham, J.; Bhadauria, V.S. Green supply chain management practices: Impact on performance. Supply Chain Manag. Int. J. 2012, 17, 290-305. [CrossRef]

6. de Vries, G.J.; Ferrarini, B. What Accounts for the Growth of Carbon Dioxide Emissions in Advanced and Emerging Economies? The Role of Consumption, Technology and Global Supply Chain Participation. Ecol. Econ. 2017, 132, 213-223. [CrossRef]

7. Wittstruck, D.; Teuteberg, F. Understanding the Success Factors of Sustainable Supply Chain Management: Empirical Evidence from the Electrics and Electronics Industry. Corp. Soc. Responsib. Environ. Manag. 2012, 19, 141-158. [CrossRef]

8. Carter, C.; Easton, P.L. Sustainable supply chain management: Evolution and future directions. Int. J. Phys. Distrib. Logist. Manag. 2011, 41, 46-59. [CrossRef]

9. Shou, Y.; Shao, J.; Lai, K.-h.; Kang, M.; Park, Y. The impact of sustainability and operations orientations on sustainable supply management and the triple bottom line. J. Clean. Prod. 2019, 240, 118280. [CrossRef]

10. Padhi, S.S.; Pati, R.K.; Rajeev, A. Framework for selecting sustainable supply chain processes and industries using an integrated approach. J. Clean. Prod. 2018, 184, 969-984. [CrossRef]

11. Govindan, K.; Khodaverdi, R.; Jafarian, A. A fuzzy multi criteria approach for measuring sustainability performance of a supplier based on triple bottom line approach. J. Clean. Prod. 2013, 47, 345-354. [CrossRef]

12. Burki, U.; Ersoy, P.; Dahlstrom, R. Achieving triple bottom line performance in manufacturer-customer supply chains: Evidence from an emerging economy. J. Clean. Prod. 2018, 197, 1307-1316. [CrossRef]

13. Kusi-Sarpong, S.; Gupta, H.; Sarkis, J. A supply chain sustainability innovation framework and evaluation methodology. IJPR 2018, 57, 1990-2008. [CrossRef]

14. Sarkis, J.; Dhavale, D.G. Supplier selection for sustainable operations: A triple-bottom-line approach using a Bayesian framework. Int. J. Prod. Econ. 2015, 166, 177-191. [CrossRef]

15. Ahi, P.; Searcy, C. Assessing sustainability in the supply chain: A triple bottom line approach. Appl. Math. Model. 2015, 39, 2882-2896. [CrossRef]

16. Mani, V.; Gunasekaran, A. Four forces of supply chain social sustainability adoption in emerging economies. Int. J. Prod. Econ. 2018, 199, 150-161. [CrossRef]

17. Cole, R.; Aitken, J. Selecting suppliers for socially sustainable supply chain management:post-exchange supplier development activities as pre-selection requirements. Prod. Plan. Control 2019, 30, 1184-1202. [CrossRef] 
18. Bai, C.; Kusi-Sarpong, S.; Badri Ahmadi, H.; Sarkis, J. Social sustainable supplier evaluation and selection: A group decisionsupport approach. IJPR 2019, 1-22. [CrossRef]

19. Mani, V.; Gunasekaran, A.; Papadopoulos, T.; Hazen, B.; Dubey, R. Supply chain social sustainability for developing nations: Evidence from India. Resour. Conserv. Recycl. 2016, 111, 42-52. [CrossRef]

20. Mani, V.; Gunasekaran, A.; Delgado, C. Supply chain social sustainability: Standard adoption practices in Portuguese manufacturing firms. Int. J. Prod. Econ. 2018, 198, 149-164. [CrossRef]

21. Mani, V.; Gunasekaran, A.; Delgado, C. Enhancing supply chain performance through supplier social sustainability: An emerging economy perspective. Int. J. Prod. Econ. 2018, 195, 259-272. [CrossRef]

22. Govindan, K.; Rajendran, S.; Sarkis, J.; Murugesan, P. Multi criteria decision making approaches for green supplier evaluation and selection: A literature review. J. Clean. Prod. 2015, 98, 66-83. [CrossRef]

23. Kazancoglu, Y.; Kazancoglu, I.; Sagnak, M. Fuzzy DEMATEL-based green supply chain management performance. Ind. Manag. Data Syst. 2018, 118, 412-431. [CrossRef]

24. dos Santos, B.M.; Godoy, L.P.; Campos, L.M.S. Performance evaluation of green suppliers using entropy-TOPSIS-F. J. Clean. Prod. 2019, 207, 498-509. [CrossRef]

25. $\mathrm{Wu}, \mathrm{H} .-\mathrm{H} . ;$ Chang, S.-Y. A case study of using DEMATEL method to identify critical factors in green supply chain management. Appl. Math. Comput. 2015, 256, 394-403. [CrossRef]

26. Rostamzadeh, R.; Govindan, K.; Esmaeili, A.; Sabaghi, M. Application of fuzzy VIKOR for evaluation of green supply chain management practices. Ecol. Indic. 2015, 49, 188-203. [CrossRef]

27. Pourjavad, E.; Shahin, A. The Application of Mamdani Fuzzy Inference System in Evaluating Green Supply Chain Management Performance. Int. J. Fuzzy Syst. 2017, 20, 901-912. [CrossRef]

28. Kazancoglu, Y.; Kazancoglu, I.; Sagnak, M. A new holistic conceptual framework for green supply chain management performance assessment based on circular economy. J. Clean. Prod. 2018, 195, 1282-1299. [CrossRef]

29. Islam, M.S.; Tseng, M.-L.; Karia, N.; Lee, C.-H. Assessing green supply chain practices in Bangladesh using fuzzy importance and performance approach. Resour. Conserv. Recycl. 2018, 131, 134-145. [CrossRef]

30. Stevenson, M.; Cole, R. Modern slavery in supply chains: A secondary data analysis of detection, remediation and disclosure. Supply Chain Manag. Int. J. 2018, 23, 81-99. [CrossRef]

31. Mani, V.; Agrawal, R.; Sharma, V. Social sustainability in the supply chain: Analysis of enablers. Manag. Res. Rev. 2015, 38, 1016-1042. [CrossRef]

32. Khosravi, F.; Izbirak, G. A stakeholder perspective of social sustainability measurement in healthcare supply chain management. Sustain. Cities Soc. 2019, 50, 101681. [CrossRef]

33. Badri Ahmadi, H.; Kusi-Sarpong, S.; Rezaei, J. Assessing the social sustainability of supply chains using Best Worst Method. Resour. Conserv. Recycl. 2017, 126, 99-106. [CrossRef]

34. Hussain, M.; Ajmal, M.M.; Gunasekaran, A.; Khan, M. Exploration of social sustainability in healthcare supply chain. J. Clean. Prod. 2018, 203, 977-989. [CrossRef]

35. Tseng, M.-L.; Islam, M.S.; Karia, N.; Fauzi, F.A.; Afrin, S. A literature review on green supply chain management: Trends and future challenges. Resour. Conserv. Recycl. 2019, 141, 145-162. [CrossRef]

36. Maditati, D.R.; Munim, Z.H.; Schramm, H.-J.; Kummer, S. Recycling, A review of green supply chain management: From bibliometric analysis to a conceptual framework and future research directions. Resour. Conserv. Recycl. 2018, 139, 150-162. [CrossRef]

37. Fahimnia, B.; Sarkis, J.; Davarzani, H. Green supply chain management: A review and bibliometric analysis. Green Supply Chain Manag. A Rev. Bibliometr. Anal. 2015, 162, 101-114. [CrossRef]

38. Touboulic, A.; Walker, H. Theories in sustainable supply chain management: A structured literature review. Int. J. Phys. Distrib. Logist. Manag. 2015, 45, 16-42. [CrossRef]

39. Rajeev, A.; Pati, R.K.; Padhi, S.S.; Govindan, K. Evolution of sustainability in supply chain management: A literature review. J. Clean. Prod. 2017, 162, 299-314. [CrossRef]

40. Ansari, Z.N.; Kant, R. A state-of-art literature review reflecting 15 years of focus on sustainable supply chain management. J. Clean. Prod. 2017, 142, 2524-2543. [CrossRef]

41. Ghadimi, P.; Wang, C.; Lim, M.K. Sustainable supply chain modeling and analysis: Past debate, present problems and future challenges. Resour. Conserv. Recycl. 2019, 140, 72-84. [CrossRef]

42. Bubicz, M.E.; Barbosa-Póvoa, A.P.F.D.; Carvalho, A. Incorporating social aspects in sustainable supply chains: Trends and future directions. J. Clean. Prod. 2019, 237, 117500. [CrossRef]

43. Koberg, E.; Longoni, A. A systematic review of sustainable supply chain management in global supply chains. J. Clean. Prod. 2019, 207, 1084-1098. [CrossRef]

44. Saeed, M.A.; Kersten, W. Drivers of sustainable supply chain management: Identification and classification. Sustainability 2019, 11, 1137. [CrossRef]

45. Banasik, A.; Bloemhof-Ruwaard, J.M.; Kanellopoulos, A.; Claassen, G.D.H.; van der Vorst, J.G.A.J. Multi-criteria decision making approaches for green supply chains: A review. Flex. Serv. Manuf. J. 2016, 30, 366-396. [CrossRef]

46. Zandieh, M.; Aslani, B. A hybrid MCDM approach for order distribution in a multiple-supplier supply chain: A case study. J. Ind. Inf. Integr. 2019, 16, 100104. [CrossRef] 
47. Luthra, S.; Mangla, S.K.; Shankar, R.; Prakash Garg, C.; Jakhar, S. Modelling critical success factors for sustainability initiatives in supply chains in Indian context using Grey-DEMATEL. Prod. Plan. Control 2018, 29, 705-728. [CrossRef]

48. Sharma, Y.K.; Mangla, S.K.; Patil, P.P.; Uniyal, S. Sustainable Food Supply Chain Management Implementation Using DEMATEL Approach. In Advances in Health and Environment Safety; Springer: Singapore, 2018; pp. 115-125.

49. Wu, K.-J.; Liao, C.-J.; Tseng, M.-L.; Chiu, A.S.F. Exploring decisive factors in green supply chain practices under uncertainty. Int. J. Prod. Econ. 2015, 159, 147-157. [CrossRef]

50. Bhagawati, M.T.; Manavalan, E.; Jayakrishna, K.; Venkumar, P. Identifying Key Success Factors of Sustainability in Supply Chain Management for Industry 4.0 Using DEMATEL Method. In Proceedings of the International Conference on Intelligent Manufacturing and Automation, Penang, Malaysia, 18-20 December 2018; pp. 583-591.

51. Gandhi, S.; Mangla, S.K.; Kumar, P.; Kumar, D. Evaluating factors in implementation of successful green supply chain management using DEMATEL: A case study. Int. Strateg. Manag. Rev. 2015, 3, 96-109. [CrossRef]

52. Gardas, B.B.; Raut, R.D.; Narkhede, B. Modelling the challenges to sustainability in the textile and apparel (T\&A) sector: A Delphi-DEMATEL approach. Sustain. Prod. Consum. 2018, 15, 96-108.

53. Bhatia, M.S.; Srivastava, R.K. Analysis of external barriers to remanufacturing using grey-DEMATEL approach: An Indian perspective. Resour. Conserv. Recycl. 2018, 136, 79-87. [CrossRef]

54. Kaur, J.; Sidhu, R.; Awasthi, A.; Chauhan, S.; Goyal, S. A DEMATEL based approach for investigating barriers in green supply chain management in Canadian manufacturing firms. IJPR 2017, 56, 312-332. [CrossRef]

55. Luthra, S.; Govindan, K.; Mangla, S.K. Structural model for sustainable consumption and production adoption-A greyDEMATEL based approach. Resour. Conserv. Recycl. 2017, 125, 198-207. [CrossRef]

56. Luthra, S.; Mangla, S.K.; Chan, F.T.S.; Venkatesh, V.G. Evaluating the Drivers to Information and Communication Technology for Effective Sustainability Initiatives in Supply Chains. Int. J. Inf. Technol. Decis. Mak. 2018, 17, 311-338. [CrossRef]

57. Su, C.-M.; Horng, D.-J.; Tseng, M.-L.; Chiu, A.S.F.; Wu, K.-J.; Chen, H.-P. Improving sustainable supply chain management using a novel hierarchical grey-DEMATEL approach. J. Clean. Prod. 2016, 134, 469-481. [CrossRef]

58. Li, Y.; Mathiyazhagan, K. Application of DEMATEL approach to identify the influential indicators towards sustainable supply chain adoption in the auto components manufacturing sector. J. Clean. Prod. 2018, 172, 2931-2941. [CrossRef]

59. Govindan, K.; Khodaverdi, R.; Vafadarnikjoo, A. Intuitionistic fuzzy based DEMATEL method for developing green practices and performances in a green supply chain. Expert Syst. Appl. 2015, 42, 7207-7220. [CrossRef]

60. Lin, K.-P.; Tseng, M.-L.; Pai, P.-F. Sustainable supply chain management using approximate fuzzy DEMATEL method. Resour. Conserv. Recycl. 2018, 128, 134-142. [CrossRef]

61. Luthra, S.; Mangla, S.K.; Xu, L.; Diabat, A. Using AHP to evaluate barriers in adopting sustainable consumption and production initiatives in a supply chain. Int. J. Prod. Econ. 2016, 181, 342-349. [CrossRef]

62. Shen, L.; Muduli, K.; Barve, A. Developing a sustainable development framework in the context of mining industries: AHP approach. Resour. Policy 2015, 46, 15-26. [CrossRef]

63. Luthra, S.; Mangla, S.K. Evaluating challenges to Industry 4.0 initiatives for supply chain sustainability in emerging economies. Process Saf. Environ. Prot. 2018, 117, 168-179. [CrossRef]

64. Mathiyazhagan, K.; Diabat, A.; Al-Refaie, A.; Xu, L. Application of analytical hierarchy process to evaluate pressures to implement green supply chain management. J. Clean. Prod. 2015, 107, 229-236. [CrossRef]

65. Gupta, S.; Dangayach, G.S.; Singh, A.K.; Rao, P.N. Analytic Hierarchy Process (AHP) Model for Evaluating Sustainable Manufacturing Practices in Indian Electrical Panel Industries. Procedia Soc. Behav. Sci. 2015, 189, 208-216. [CrossRef]

66. Shankar, K.; Kumar, P.; Kannan, D. Analyzing the Drivers of Advanced Sustainable Manufacturing System Using AHP Approach. Sustainability 2016, 8, 824. [CrossRef]

67. Mangla, S.K.; Kumar, P.; Barua, M.K. Risk analysis in green supply chain using fuzzy AHP approach: A case study. Resour. Conserv. Recycl. 2015, 104, 375-390. [CrossRef]

68. Sharma, Y.K.; Yadav, A.K.; Mangla, S.K.; Patil, P.P. Ranking the Success Factors to Improve Safety and Security in Sustainable Food Supply Chain Management Using Fuzzy AHP. Mater. Today Proc. 2018, 5, 12187-12196. [CrossRef]

69. Kumar, D.; Garg, C.P. Evaluating sustainable supply chain indicators using fuzzy AHP. Benchmarking Int. J. 2017, 24, 1742-1766. [CrossRef]

70. Mejías, A.M.; Bellas, R.; Pardo, J.E.; Paz, E. Traceability management systems and capacity building as new approaches for improving sustainability in the fashion multi-tier supply chain. Int. J. Prod. Econ. 2019, 217, 143-158. [CrossRef]

71. Mastrocinque, E.; Ramírez, F.J.; Honrubia-Escribano, A.; Pham, D.T. An AHP-based multi-criteria model for sustainable supply chain development in the renewable energy sector. Expert Syst. Appl. 2020, 150, 113321. [CrossRef]

72. Li, J.; Fang, H.; Song, W. Sustainable supplier selection based on SSCM practices: A rough cloud TOPSIS approach. J. Clean. Prod. 2019, 222, 606-621. [CrossRef]

73. Bai, C.; Sarkis, J. Integrating Sustainability into Supplier Selection: A Grey-Based Topsis Analysis. Technol. Econ. Dev. Econ. 2018, 24, 2202-2224. [CrossRef]

74. Shen, L.; Olfat, L.; Govindan, K.; Khodaverdi, R.; Diabat, A. A fuzzy multi criteria approach for evaluating green supplier's performance in green supply chain with linguistic preferences. Resour. Conserv. Recycl. 2013, 74, 170-179. [CrossRef]

75. Rouyendegh, B.D.; Yildizbasi, A.; Üstünyer, P. Intuitionistic Fuzzy TOPSIS method for green supplier selection problem. Soft Comput. 2020, 24, 2215-2228. [CrossRef] 
76. Rashidi, K.; Cullinane, K. A comparison of fuzzy DEA and fuzzy TOPSIS in sustainable supplier selection: Implications for sourcing strategy. Expert Syst. Appl. 2019, 121, 266-281. [CrossRef]

77. Memari, A.; Dargi, A.; Akbari Jokar, M.R.; Ahmad, R.; Abdul Rahim, A.R. Sustainable supplier selection: A multi-criteria intuitionistic fuzzy TOPSIS method. J. Manuf. Syst. 2019, 50, 9-24. [CrossRef]

78. Wang, X.; Chan, H.K. A hierarchical fuzzy TOPSIS approach to assess improvement areas when implementing green supply chain initiatives. IJPR 2013, 51, 3117-3130. [CrossRef]

79. Suhi, S.A.; Enayet, R.; Haque, T.; Ali, S.M.; Moktadir, M.A.; Paul, S.K. Environmental sustainability assessment in supply chain: An emerging economy context. Env. Impact Assess. Rev. 2019, 79, 106306. [CrossRef]

80. Wan Ahmad, W.N.K.; Rezaei, J.; Sadaghiani, S.; Tavasszy, L.A. Evaluation of the external forces affecting the sustainability of oil and gas supply chain using Best Worst Method. J. Clean. Prod. 2017, 153, 242-252. [CrossRef]

81. Rezaei, J.; Papakonstantinou, A.; Tavasszy, L.; Pesch, U.; Kana, A. Sustainable product-package design in a food supply chain: A multi-criteria life cycle approach. Packag. Technol. Sci. 2019, 32, 85-101. [CrossRef]

82. Jafarzadeh Ghoushchi, S.; Khazaeili, M.; Amini, A.; Osgooei, E. Multi-criteria sustainable supplier selection using piecewise linear value function and fuzzy best-worst method. J. Intell. Fuzzy Syst. 2019, 37, 2309-2325. [CrossRef]

83. Gupta, H.; Kusi-Sarpong, S.; Rezaei, J. Barriers and overcoming strategies to supply chain sustainability innovation. Resour. Conserv. Recycl. 2020, 161, 104819. [CrossRef]

84. Awasthi, A.; Kannan, G. Green supplier development program selection using NGT and VIKOR under fuzzy environment. Comput. Ind. Eng. 2016, 91, 100-108. [CrossRef]

85. Haji Vahabzadeh, A.; Asiaei, A.; Zailani, S. Green decision-making model in reverse logistics using FUZZY-VIKOR method. Resour. Conserv. Recycl. 2015, 103, 125-138. [CrossRef]

86. Haji Vahabzadeh, A.; Asiaei, A.; Zailani, S. Reprint of "Green decision-making model in reverse logistics using FUZZY-VIKOR method". Resour. Conserv. Recycl. 2015, 104, 334-347. [CrossRef]

87. Zhang, X.; Xing, X. Probabilistic Linguistic VIKOR Method to Evaluate Green Supply Chain Initiatives. Sustainability 2017, 9 , 1231. [CrossRef]

88. Bai, C.; Sarkis, J. Integrating sustainability into supplier selection with grey system and rough set methodologies. Int. J. Prod. Econ. 2010, 124, 252-264. [CrossRef]

89. Bai, C.; Sarkis, J. Green supplier development: Analytical evaluation using rough set theory. J. Clean. Prod. 2010, 18, 1200-1210. [CrossRef]

90. Bai, C.; Sarkis, J.; Wei, X. Addressing key sustainable supply chain management issues using rough set methodology. Manag. Res. Rev. 2010, 33, 1113-1127. [CrossRef]

91. Bai, C.; Sarkis, J. Performance Measurement and Evaluation for Sustainable Supply Chains using Rough Set and Data Envelopment Analysis. In Sustainable Supply Chains; Springer: New York, NY, USA, 2012; pp. 223-241.

92. Costa, A.S.; Govindan, K.; Figueira, J.R. Supplier classification in emerging economies using the ELECTRE TRI-nC method: A case study considering sustainability aspects. J. Clean. Prod. 2018, 201, 925-947. [CrossRef]

93. Kumar, P.; Singh, R.K.; Vaish, A. Suppliers' green performance evaluation using fuzzy extended ELECTRE approach. Clean Technol. Environ. Policy 2016, 19, 809-821. [CrossRef]

94. Lin, C.; Madu, C.N.; Kuei, C.-h.; Tsai, H.-L.; Wang, K.-n. Developing an assessment framework for managing sustainability programs: A Analytic Network Process approach. Expert Syst. Appl. 2015, 42, 2488-2501. [CrossRef]

95. Faisal, M.N.; Al-Esmael, B.; Sharif, K.J. Supplier selection for a sustainable supply chain. Benchmarking Int. J. 2017, 24, 1956-1976. [CrossRef]

96. Song, W.; Ming, X.; Liu, H.-C. Identifying critical risk factors of sustainable supply chain management: A rough strength-relation analysis method. J. Clean. Prod. 2017, 143, 100-115. [CrossRef]

97. Stević, Ž.; Durmić, E.; Gajić, M.; Pamučar, D.; Puška, A. A Novel Multi-Criteria Decision-Making Model: Interval Rough SAW Method for Sustainable Supplier Selection. Information 2019, 10, 292. [CrossRef]

98. Raut, R.; Gardas, B.B.; Narkhede, B. Ranking the barriers of sustainable textile and apparel supply chains. Benchmarking: Int. J. 2019, 26, 371-394. [CrossRef]

99. Pehlken, A.; Wulf, K.; Grecksch, K.; Klenke, T.; Tsydenova, N. More Sustainable Bioenergy by Making Use of Regional Alternative Biomass? Sustainability 2020, 12, 7849. [CrossRef]

100. Sirisawat, P.; Kiatcharoenpol, T. Fuzzy AHP-TOPSIS approaches to prioritizing solutions for reverse logistics barriers. Comput. Ind. Eng. 2018, 117, 303-318. [CrossRef]

101. Singh, R.K.; Gunasekaran, A.; Kumar, P. Third party logistics (3PL) selection for cold chain management: A fuzzy AHP and fuzzy TOPSIS approach. AnOR 2017, 267, 531-553. [CrossRef]

102. Mangla, S.K.; Kumar, P.; Barua, M.K. Prioritizing the responses to manage risks in green supply chain: An Indian plastic manufacturer perspective. Sustain. Prod. Consum. 2015, 1, 67-86. [CrossRef]

103. Freeman, J.; Gary Graham, D.; Chen, T. Green supplier selection using an AHP-Entropy-TOPSIS framework. Supply Chain Manag. Int. J. 2015, 20, 327-340. [CrossRef]

104. Azimifard, A.; Moosavirad, S.H.; Ariafar, S. Selecting sustainable supplier countries for Iran's steel industry at three levels by using AHP and TOPSIS methods. Resour. Policy 2018, 57, 30-44. [CrossRef]

105. Mohammed, A.; Harris, I.; Govindan, K. A hybrid MCDM-FMOO approach for sustainable supplier selection and order allocation. Int. J. Prod. Econ. 2019, 217, 171-184. [CrossRef] 
106. Sari, K. A novel multi-criteria decision framework for evaluating green supply chain management practices. Comput. Ind. Eng. 2017, 105, 338-347. [CrossRef]

107. Luthra, S.; Govindan, K.; Kannan, D.; Mangla, S.K.; Garg, C.P. An integrated framework for sustainable supplier selection and evaluation in supply chains. J. Clean. Prod. 2017, 140, 1686-1698. [CrossRef]

108. Awasthi, A.; Govindan, K.; Gold, S. Multi-tier sustainable global supplier selection using a fuzzy AHP-VIKOR based approach Int. J. Prod. Econ. 2018, 195, 106-117. [CrossRef]

109. Gandhi, S.; Mangla, S.K.; Kumar, P.; Kumar, D. A combined approach using AHP and DEMATEL for evaluating success factors in implementation of green supply chain management in Indian manufacturing industries. Int. J. Logist. Res. Appl. 2016, 19, 537-561. [CrossRef]

110. Uddin, S.; Ali, S.M.; Kabir, G.; Suhi, S.A.; Enayet, R.; Haque, T. An AHP-ELECTRE framework to evaluate barriers to green supply chain management in the leather industry. Int. J. Sustain. Dev. World Ecol. 2019, 1-20. [CrossRef]

111. Kumar, D.; Rahman, Z.; Huang, Z.; Wang, K. Analyzing enablers of sustainable supply chain: ISM and Fuzzy AHP approach. J. Model. Manag. 2017, 12, 498-524. [CrossRef]

112. Sreekumar, V.; Rajmohan, M. Supply chain strategy decisions for sustainable development using an integrated multi-criteria decision-making approach. Sustain. Dev. 2019, 27, 50-60. [CrossRef]

113. Tavana, M.; Yazdani, M.; Di Caprio, D. An application of an integrated ANP-QFD framework for sustainable supplier selection. Int. J. Logist. Res. Appl. 2016, 20, 254-275. [CrossRef]

114. Lam, J.S.L.; Lai, K.-h. Developing environmental sustainability by ANP-QFD approach: The case of shipping operations. J. Clean. Prod. 2015, 105, 275-284. [CrossRef]

115. Lam, J.S.L.; Dai, J. Environmental sustainability of logistics service provider: An ANP-QFD approach. Int. J. Logist. Manag. 2015, 26, 313-333. [CrossRef]

116. Lam, J.S.L. Designing a sustainable maritime supply chain: A hybrid QFD-ANP approach. Transp. Res. Part E Logist. Transp. Rev. 2015, 78, 70-81. [CrossRef]

117. Liu, K.; Liu, Y.; Qin, J. An integrated ANP-VIKOR methodology for sustainable supplier selection with interval type-2 fuzzy sets. Granul. Comput. 2018, 3, 193-208. [CrossRef]

118. Hashemi, S.H.; Karimi, A.; Tavana, M. An integrated green supplier selection approach with analytic network process and improved Grey relational analysis. Int. J. Prod. Econ. 2015, 159, 178-191. [CrossRef]

119. Paul, A.; Moktadir, M.A.; Paul, S.K. An innovative decision-making framework for evaluating transportation service providers based on sustainable criteria. IJPR 2020, 58, 7334-7352. [CrossRef]

120. Garg, C.P.; Sharma, A. Sustainable outsourcing partner selection and evaluation using an integrated BWM-VIKOR framework. Env. Dev. Sustain. 2018, 1-29. [CrossRef]

121. Kumar, A.; Mangla, S.K.; Luthra, S.; Ishizaka, A. Evaluating the human resource related soft dimensions in green supply chain management implementation. Prod. Plan. Control 2019, 30, 699-715. [CrossRef]

122. Liu, H.-C.; Quan, M.-Y.; Li, Z.; Wang, Z.-L. A new integrated MCDM model for sustainable supplier selection under intervalvalued intuitionistic uncertain linguistic environment. Inf. Sci. 2019, 486, 254-270. [CrossRef]

123. Jain, N.; Singh, A.R.; Upadhyay, R.K. Sustainable supplier selection under attractive criteria through FIS and integrated fuzzy MCDM techniques. Int. J. Sustain. Eng. 2020, 13, 441-462. [CrossRef]

124. Papathanasiou, J.P.; Nikolaos, P.; Bournaris, T.; Manos, B. A Decision Support System for Multiple Criteria Alternative Ranking Using TOPSIS and VIKOR: A Case Study on Social Sustainability in Agriculture. In Decision Support Systems VI-Addressing Sustainability and Societal Challenges, Lecture Notes in Business Information Processing; Springer International Publishing: Basel, Switzerland, 2016; pp. 1-13.

125. Bai, C.; Sarkis, J. Integrating and extending data and decision tools for sustainable third-party reverse logistics provider selection. Comput. Oper. Res. 2019, 110, 188-207. [CrossRef]

126. Bhatia, M.S.; Dora, M.; Jakhar, S.K. Appropriate location for remanufacturing plant towards sustainable supply chain. AnOR 2019, 1-22. [CrossRef]

127. Kusi-Sarpong, S.; Bai, C.; Sarkis, J.; Wang, X. Green supply chain practices evaluation in the mining industry using a joint rough sets and fuzzy TOPSIS methodology. Resour. Policy 2015, 46, 86-100. [CrossRef]

128. Rostamzadeh, R.; Ghorabaee, M.K.; Govindan, K.; Esmaeili, A.; Nobar, H.B.K. Evaluation of sustainable supply chain risk management using an integrated fuzzy TOPSIS- CRITIC approach. J. Clean. Prod. 2018, 175, 651-669.

129. Fallahpour, A.; Udoncy Olugu, E.; Nurmaya Musa, S.; Yew Wong, K.; Noori, S. A decision support model for sustainable supplier selection in sustainable supply chain management. Comput. Ind. Eng. 2017, 105, 391-410. [CrossRef]

130. Chithambaranathan, P.; Subramanian, N.; Gunasekaran, A.; Palaniappan, P.K. Service supply chain environmental performance evaluation using grey based hybrid MCDM approach. Int. J. Prod. Econ. 2015, 166, 163-176. [CrossRef]

131. Yazdani, M.; Pamucar, D.; Chatterjee, P.; Chakraborty, S. Development of a decision support framework for sustainable freight transport system evaluation using rough numbers. IJPR 2019, 1-27. [CrossRef]

132. Matić, B.; Jovanović, S.; Das, D.K.; Zavadskas, E.K.; Stević, Ž.; Sremac, S.; Marinković, M. A New Hybrid MCDM Model: Sustainable Supplier Selection in a Construction Company. Symmetry 2019, 11, 353.

133. Roy, J.; Pamučar, D.; Kar, S. Evaluation and selection of third party logistics provider under sustainability perspectives: An interval valued fuzzy-rough approach. AnOR 2020, 293, 669-714. [CrossRef] 
134. Ansari, Z.N.; Kant, R.; Shankar, R. Evaluation and ranking of solutions to mitigate sustainable remanufacturing supply chain risks: A hybrid fuzzy SWARA-fuzzy COPRAS framework approach. Int. J. Sustain. Eng. 2020, 13, 473-494. [CrossRef]

135. Erol, I.; Sencer, S.; Sari, R. A new fuzzy multi-criteria framework for measuring sustainability performance of a supply chain. Ecol. Econ. 2011, 70, 1088-1100. [CrossRef]

136. Muhammad, N.; Fang, Z.; Shah, S.A.A.; Akbar, M.A.; Alsanad, A.; Gumaei, A.; Solangi, Y.A. A Hybrid Multi-Criteria Approach for Evaluation and Selection of Sustainable Suppliers in the Avionics Industry of Pakistan. Sustainability 2020, 12, 4744. [CrossRef]

137. Sharma, R.K.; Singh, P.K.; Sarkar, P.; Singh, H. A hybrid multi-criteria decision approach to analyze key factors affecting sustainability in supply chain networks of manufacturing organizations. Clean Technol. Environ. Policy 2020, 22, 1871-1889. [CrossRef]

138. Phochanikorn, P.; Tan, C. A New Extension to a Multi-Criteria Decision-Making Model for Sustainable Supplier Selection under an Intuitionistic Fuzzy Environment. Sustainability 2019, 11, 5413. [CrossRef]

139. Chauhan, A.; Kaur, H.; Yadav, S.; Jakhar, S.K. A hybrid model for investigating and selecting a sustainable supply chain for agri-produce in India. AnOR 2019, 290, 621-642. [CrossRef]

140. Tirkolaee, E.B.; Mardani, A.; Dashtian, Z.; Soltani, M.; Weber, G.-W. A novel hybrid method using fuzzy decision making and multi-objective programming for sustainable-reliable supplier selection in two-echelon supply chain design. J. Clean. Prod. 2020, 250, 119517. [CrossRef]

141. Yazdani, M.; Torkayesh, A.E.; Chatterjee, P. An integrated decision-making model for supplier evaluation in public healthcare system: The case study of a Spanish hospital. J. Enterp. Inf. Manag. 2020, 33, 965-989. [CrossRef]

142. Abdel-Basset, M.; Mohamed, R.; Sallam, K.; Elhoseny, M. A novel decision-making model for sustainable supply chain finance under uncertainty environment. J. Clean. Prod. 2020, 269, 122324. [CrossRef]

143. Rajesh, R. Sustainable supply chains in the Indian context: An integrative decision-making model. Technol. Soc. 2020, 61, 101230. [CrossRef]

144. Abdel-Basset, M.; Mohamed, R. A novel plithogenic TOPSIS- CRITIC model for sustainable supply chain risk management. J. Clean. Prod. 2020, 247, 119586. [CrossRef]

145. Chen, C. A New Multi-Criteria Assessment Model Combining GRA Techniques with Intuitionistic Fuzzy Entropy-Based TOPSIS Method for Sustainable Building Materials Supplier Selection. Sustainability 2019, 11, 2265. [CrossRef]

146. Seuring, S. A review of modeling approaches for sustainable supply chain management. Decis. Support Syst. 2013, 54, 1513-1520. [CrossRef]

147. Zavadskas, E.K.; Govindan, K.; Antucheviciene, J.; Turskis, Z. Hybrid multiple criteria decision-making methods: A review of applications for sustainability issues. Econ. Res. Ekon. Istraživanja 2016, 29, 857-887. [CrossRef]

148. Schramm, V.B.; Cabral, L.P.B.; Schramm, F. Approaches for supporting sustainable supplier selection-A literature review. J. Clean. Prod. 2020, 273, 123089. [CrossRef]

149. Gandhi, N.S.; Thanki, S.J.; Thakkar, J.J. Ranking of drivers for integrated lean-green manufacturing for Indian manufacturing SMEs. J. Clean. Prod. 2018, 171, 675-689. [CrossRef]

150. Gupta, H.; Barua, M.K. A novel hybrid multi-criteria method for supplier selection among SMEs on the basis of innovation ability. Int. J. Logist. Res. Appl. 2017, 21, 201-223. [CrossRef]

151. Raut, R.D.; Gardas, B.B.; Narkhede, B.E.; Narwane, V.S. To investigate the determinants of cloud computing adoption in the manufacturing micro, small and medium enterprises. Benchmarking Int. J. 2019, 26, 990-1019. [CrossRef]

152. Tsai, W.-H.; Lee, P.-L.; Shen, Y.-S.; Hwang, E.T.Y. A combined evaluation model for encouraging entrepreneurship policies. AnOR 2011, 221, 449-468. [CrossRef]

153. Rezaei, J. Best-worst multi-criteria decision-making method: Some properties and a linear model. Omega 2016, 64, 126-130. [CrossRef]

154. Chowdhury, P.; Paul, S.K.; Kaisar, S.; Moktadir, M.A. COVID-19 pandemic related supply chain studies: A systematic review. Transp. Res. E Logist Transp. Rev. 2021, 148, 102271. [CrossRef]

155. Sabuj, S.U.; Ali, S.M.; Hasan, K.W.; Paul, S.K. Contextual relationships among key factors related to environmental sustainability: Evidence from an emerging economy. Sustain. Prod. Consum. 2021, 27, 86-99. [CrossRef]

156. Ali, S.M.; Paul, S.K.; Chowdhury, P.; Agarwal, R.; Fathollahi-Fard, A.M.; Jabbour, C.J.C.; Luthra, S. Modelling of supply chain disruption analytics using an integrated approach: An emerging economy example. Expert Syst. Appl. 2021, 173, 114690. 